\title{
Timing and duration of Palaeoproterozoic events producing ore-bearing layered intrusions of the Baltic Shield: metallogenic, petrological and geodynamic implications
}

\author{
T. Bayanova ${ }^{1}$, J. Ludden ${ }^{2}$, and F. Mitrofanov ${ }^{1}$ \\ 1) Geological Institute, Kola Science Centre RAS, 14 Fersman St., Apatity, Russia \\ 2) British Geological Survey, Keyworth, Nottingham NG12 5GG,UKjludden@bgs.ac.uk \\ E-mail:tamara@geoksc.apatity.ru
}

\begin{abstract}
There are two 300-500-km long belts of Palaeoproterozoic layered intrusions: the Northern (Kola) Belt and the Southern (Fenno-Karelian) Belt in the Baltic (Fennoscandian) Shield. New U-Pb (TIMS) ages and radiogenic isotopic (Nd-Sr-He) data have been determined for mafic-ultramafic $\mathrm{Cu}-\mathrm{Ni}-\mathrm{Ti}-\mathrm{Cr}$ and PGEbearing layered intrusions of the Kola Belt. U-Pb ages on zircon and baddeleyite for gabbronorite and anorthosite from the Fedorovo-Pansky, Monchepluton and Main Ridge (Monchetundra and Chunatundra), Mt. Generalskaya intrusions and gabbronorite and dykes from the Imandra lopolith of the Kola Belt define a time interval of more than 130 million years, from ca. $2.52 \mathrm{Ga}$ to $2.39 \mathrm{Ga}$. At least four intrusive phases have been distinguished: three PGE-bearing, and one barren. This spread of ages is wider than that for intrusions of the Fenno-Karelian Belt which clusters at $2.44 \mathrm{Ga}$. Nd isotopic values for the Northern Belt range from 1.1 to -2.4 , implying an enriched mantle "EM-1 type" reservoir for these layered intrusions. Initial Sr isotopic data for the rocks of the intrusions are radiogenic relative to bulk mantle, with $\mathrm{I}_{\mathrm{Sr}}$ values from 0.703 to 0.704 . Geochemical data and ${ }^{4} \mathrm{He} /{ }^{3} \mathrm{He}$ isotopic ratios of the minerals reflect a significant contribution from a mantle source rather than the influence of crustal processes during emplacement. The geological and geochronological data indicate that in the eastern part of the Baltic Shield, mafic - ultramafic intrusive magmatism was active over a protracted period and was related to plume magmatism associated with continental breakup that also involved the Superior and Wyoming provinces.
\end{abstract}

Key words: geochronology, isotopes, Palaeoproterozoic, layered PGE-bearing intrusions, Baltic Shield.

There are about twenty Palaeoproterozoic layered mafic-ultramafic bodies in Finland, most of which occur in a roughly eastwest-trending, 300-km long belt known as the Tornio-Näränkävaara Belt (Alapieti et al., 1990; Vogel et al., 1998; Iljina \& Hanski, 2005). The belt (Fig. 1) extends for a few kilometres into Sweden (Tornio intrusion), and for several tens of kilometres into the Russian Karelia (Olanga complex). Together the intrusions make up the Southern, or Fenno-Karelian Belt FKB (Mitrofanov et al., 1997).

In the northeast of the province, the Northern, or Kola Belt (KB) strikes northwestwards for about $500 \mathrm{~km}$ (Fig.1). It includes more than ten isolated layered mafic-ultramafic bodies that are mostly ore-bearing (Mitrofanov et al., 1997). The central part of the Kola Belt has been suggested to be part of a triple junction typical of intraplate rifting (Pirajno, 2007), and is occupied by the Monchegorsk Layered Complex with a fairly complete range of ore types $(\mathrm{Cr}, \mathrm{Cu}, \mathrm{Ni}, \mathrm{Co}, \mathrm{Ti}, \mathrm{V}, \mathrm{Pt}$, 
$\mathrm{Pd}, \mathrm{Rh})$. The western and eastern arms of the triple junction are composed of large anorthositetroctolite (Main Ridge, Pyrshin, Kolvitsa) intrusions (Fig. 1). The most typical PGE-bearing layered pyroxenite-norite-gabbro-anorthosite intrusions of the Kola Belt (Mt. General'skaya, Monchegorsk Layered Complex, Fedorovo-Pansky etc.) are confined to boundaries between Early Proterozoic rifts which were in-filled with volcano-sedimentary rocks overlying the Archaean basement (Schissel et al., 2002; Mitrofanov et al., 2005). In these cases, similar to those in Finland, the intrusive rocks underwent relatively low grade local metamorphism and preserve cumulus and intracumulus minerals.

Convincing arguments in support of the mantle plume hypothesis, either as "shallow plumes" (from $\sim 670 \mathrm{~km}$ ) or "deep plumes" (from the core-mantle boundary) have been put forward for relatively young well-preserved Palaeozoic and recent large igneous provinces (LIPs) (Coffin \& Eldhom, 1994; Heaman, 1997; Ernst \& Buchan, 2003; French et al., 2008). Voluminous magmatism is considered to be related to mantle plumes that occurred throughout the Precambrian (Condie, 2001). The best records of a plume source are evident in Neoarchaean and Palaeoproterozoic magmatic events and often have associated with mineralization (Sharkov et al., 2000; Campbell, 2001; Pirajno, 2007 etc.). Many of these magmas have generated layered maficultramafic complexes with exploitable PGE deposits (Pt, Pd and $\mathrm{Rh}$ ), and $\mathrm{Cr}, \mathrm{Ni}, \mathrm{Cu}, \mathrm{Co}, \mathrm{Ti}, \mathrm{V}$ mineralization (Li \& Naldrett, 1993; Mitrofanov et al., 1997; 2005; Sharkov et al., 2000). Magmatic igneous ore systems are present in the Windimurra $(2.8 \mathrm{Ga})$, Stillwater $(2.7 \mathrm{Ga})$, Bushveld $(2.06$ Ga), and Duluth (1.1 Ga) complexes (Li \& Naldrett, 1993; Carr et al., 1999; Eules \& Cawthorn, 1995; Pirajno, 2007). Many of these intrusions include massif-type anorthosites and troctolites enriched in $\mathrm{Cr}, \mathrm{Ni}, \mathrm{Cu}, \mathrm{PGE}, \mathrm{Ti}, \mathrm{V}$ and Fe. All the above mentioned rock types, metals, host riftassociated volcanic rocks, and mafic dykes are found in the relatively recently described EastScandinavian Palaeoproterozoic Large Igneous Province (ESCLIP) (Iljina \& Hanski, 2005) with a total area of more than $200.000 \mathrm{~km}^{2}$ (Fig. 1). In Finland, these geological complexes have been widely studied (Alapieti et al., 1990; Huhma et al., 1990; Vogel et al., 1998; Hanski et al., 2001), and the data were summarized by M. Iljina and E. Hanski (2005). Only a few publications on similar Russian complexes of the Baltic Shield have been written or translated into English (Papunen \& Gorbunov et al., 1985; Balashov et al., 1993; Bayanova \& Balashov, 1995; Amelin et al., 1995; Mitrofanov et al., 1997; Mitrofanov \& Bayanova, 1999; Chashchin et al., 2002; Schissel et al., 2002; Mitrofanov et al., 2005).

This paper presents a brief geological description of the Russian mafic-ultramafic intrusions of the Baltic Shield and associated mineralization. It focuses on new U-Pb (TIMS) and Sm-Nd geochronological data which constrain timing of magmatic pulses and the duration of the emplacement of $\mathrm{Cr}, \mathrm{Cu}, \mathrm{Ni}$, Ti and PGE-bearing layered intrusions of the Kola Belt. $\mathrm{Nd}, \mathrm{Sr}$ and $\mathrm{He}$ isotope data help define geodynamic models for a long-lived Early Precambrian mantle source expressed either in a large mantle diaper or multiple plume processes for one of the earliest clearly identifiable old intraplate LIPs and its metallogeny. 


\section{Geological setting of ore-bearing intrusions of the Baltic Shield}

Palaeoproterozoic layered pyroxenite-peridotite-gabbronorite-anorthosite ore-bearing intrusions form two belts in the eastern part of the Baltic (Fennoscandian) Shield (Fig. 1). The Northern Belt includes such intrusions as Mt. General'skaya, Fedorovo-Pansky, Monchegorsk Layered Complex and Imandra lopolith, which are described in the present paper. The Southern Belt contains intrusions of the Olanga group (Kivakka, Tsipringa and Lukkulaisvaara) and the Burakovsky intrusion situated in Karelia, and some Finnish intrusions (Koilismaa, Näränkävaara, Koitilainen, Penikat, Akanvaara, Kemi etc.).

The Northern Belt strikes northwestward for over $500 \mathrm{~km}$ and is confined to the southwestern edge of the Archaean Kola-Norwegian Block and to the northern and southern borders of the Palaeoproterozoic Pechenga-Imandra-Varzuga rift.

The Southern Belt stretches approximately from east to west over $350 \mathrm{~km}$ and occupies the northern margin of the Karelian craton. The intrusions of the Southern Belt formed in a similar prerifting geodynamic setting, and are generally confined to the margins of the intracontinental rift structures and are located at contacts with the Archaean basement.

\section{Geology and petrology of the layered intrusions of the Kola Belt}

\section{Mt. General'skaya}

This intrusion (Fig. 1) has a prominent cross-cutting contact with the Archaean gneiss complex in the west. The basal conglomerates associated with the Palaeoproterozoic Pechenga rift contain abundant gabbronorite pebbles in the Luostari area. The intrusion is cut by quartz dolerite dykes, which are similar in composition to the lower volcanogenic Sariola Majarvi Suite of the Pechenga structure. The intrusion outcrops over an area of $3.5 \times 1.5 \mathrm{~km}$, but its actual size is assumed to be greater. It gently dips southwestward at an angle of $30^{\circ}-35^{\circ}$ underlying the conglomerates of the Televi Suite and volcanic andesite-basaltic flows of the Majarvi Suite, both of which constitute the lower part of the Pechenga section. The whole rock $\mathrm{Rb}-\mathrm{Sr}$ age of the volcanic sequence is $2324 \pm 28 \mathrm{Ma}$ (Bayanova et al., 1999). The northeast-trending intrusion $\left(10^{\circ}-20^{\circ}\right)$ has a keel-like shape and a well defined internal structure. The eastern and western contacts dip towards each other at angles of $60-65^{\circ}$ and $30-50^{\circ}$ respectively. The intrusion is dissected by younger faults of northeastern and northwestern strike; one of the faults separates the intrusion into two large blocks. The total thickness of the intrusive sequence increases from $200 \mathrm{~m}$ to $1700 \mathrm{~m}$ from northeast to southwest. The section is dominated by gabbro-norite, olivine gabbronorite, gabbro, anorthosite or leucogabbro, norite, bronzitite, while serpentinized peridotite is minor (Hanski et al., 1990; Bayanova et al., 1999; Skuf'in \& Bayanova, 2006 etc.). Low sulphide disseminated PGE mineralization is now being explored by a mining company.

Geological data and two zircon U-Pb ages $(2496 \pm 10 \mathrm{Ma}$ and $2446 \pm 10 \mathrm{Ma}$, see below) for the rocks of the intrusion show that anorthositic injections took place later than gabbronoritic ones (Bayanova et al., 1999). 


\section{The Fedorovo-Pansky Complex}

The Fedorovo-Pansky Layered Complex (Fig.1) outcrops over an area of more than $400 \mathrm{~km}^{2}$. It strikes northwestwards for more than $60 \mathrm{~km}$ and dips southwestwards at an angle of $30-35^{\circ}$. The total rock sequence is about $3-4 \mathrm{~km}$ thick. Tectonic dislocations divide the complex into several blocks. The major blocks from west to east (Fig. 2) are known as: the Fedorov, the Lastjavr, the Western Pansky and the Eastern Pansky (Mitrofanov et al., 2005). The Fedorovo-Pansky complex is bordered by the Archaean Keivy terrane and the Palaeoproterozoic Imandra-Varzuga rift. The rocks of the complex outcrop close to the Archaean gneisses only in the northwestern extremities, but their contacts cannot be established due to poor exposure. In the north the complex borders with the alkaline granites of the White Tundra intrusion. The alkaline granites were recently proved to be Archaean with a U-Pb zircon age of 2654 \pm 15 Ma (Bayanova, 2004; Zozulya et al., 2005). The contact of the Western Pansky Block with the Imandra-Varzuga volcano-sedimentary sequence is mostly covered by Quaternary deposits. Drilling and excavations in the south of Mt. Kamennik showed that the contact is tectonic since the intrusive and overlying Palaeoproterozoic volcanosedimentary rocks are sheared and metamorphosed.

The Fedorovo-Pansky Complex comprises predominantly gabbronorites with varying proportions of mafic minerals and different structural features (Fig. 3). From bottom up, the composite layered sequence is as follows (Fig. 3):

- Marginal Zone (50-100 m) of plagioclase-amphibole schists with relicts of massive finegrained norite and gabbronorite, which are referred to as chilled margin rocks;

- Taxitic Zone $(30-300 \mathrm{~m})$ that contains ore-bearing gabbronoritic matrix (2485 Ma, see below) and early xenoliths of plagioclase-bearing pyroxenite and norite (2526-2516 Ma, see below). Syngenetic and magmatic ores are represented by $\mathrm{Cu}$ and $\mathrm{Ni}$ sulphides with $\mathrm{Pt}, \mathrm{Pd}$ and $\mathrm{Au}$, and $\mathrm{Pt}$ and Pd sulphides, bismutho-tellurides and arsenides;

- Norite Zone $(50-200 \mathrm{~m})$ with cumulus interlayers of harzburgite and plagioclase-bearing pyroxenite that includes an intergranular injection $\mathrm{Cu}-\mathrm{Ni}$-PGE mineralization in the lower part. The rocks of the zone are enriched in chromium (up to $1000 \mathrm{ppm}$ ) and contain chromite that is also typical of the rocks of the Penikat and Kemi intrusions (Finland) derived from the earliest magma portion (Iljina \& Hanski, 2005). Basal Cu-Ni-PGE deposits of the Fedorov Block have been explored and prepared for licensing (Schissel et al., 2002; Mitrofanov et al., 2005).

- Main Gabbronorite Zone ( $1000 \mathrm{~m}$ ) that is a thickly layered "stratified" rock series (Fig. 3) with a 40-80 m thinly layered lower horizon (LLH) at the upper part. The LLH consists of contrasting alteration of gabbronorite, norite, pyroxenite and interlayers of leucocratic gabbro and anorthosite. The LLH contains a reef-type PGE deposit poor in base-metal sulphides. The deposit is now being extensively explored (Mitrofanov et al., 2005). According to the field investigations (Latypov \& Chistyakova, 2000) the LLH anorthositic layers have been intruded later as shown by 
cutting injection contacts. This is confirmed by a zircon $\mathrm{U}-\mathrm{Pb}$ age for the anorthosite of $2470 \pm 9 \mathrm{Ma}$ (see below).

- Upper Layered Horizon (ULH) between the Lower and Upper Gabbro Zones. The ULH consists of olivine-bearing troctolite, norite, gabbronorite and anorthosite (Fig. 3). It comprises several layers of rich PGE (Pd $>>P t)$ ore poor in base-metal sulphides (Mitrofanov et al., 2005). The $\mathrm{U}-\mathrm{Pb}$ age on zircon and baddeleyite of the ULH rocks of $2447 \pm 12 \mathrm{Ma}$ (see below) is the youngest among those obtained for the rocks of the Fedorovo-Pansky Complex.

The Monchepluton, intrusions of the Main Ridge (Monchetundra and Chunatundra) and adjacent intrusions - Monchegorsk Layered Complex

The Monchegorsk Layered Complex (Fig. 4) has long been the subject of detailed investigation due to the exploitation of rich $\mathrm{Cu}-\mathrm{Ni}$ ores of the Monchepluton (Papunen and Gorbunov, 1985; Chashchin and et al., 2001; Smolkin et al., 2004). The Complex is located at a triple junction (Fig. 1) where weakly metamorphosed Early Proterozoic riftogene rocks and deepseated Archaean rocks metamorphosed at granulite to amphibolite facies become contiguous at the modem erosion level. The Monchepluton is an S-shaped body with an area of ca. $65 \mathrm{~km}^{2}$. It consists of two parts which represent independent magma chambers.

The northwestern and central parts of the Monchepluton (NKT: Mts. Nittis, Kumuzh'ya and Travyanaya and Mt. Sopcha) are mainly composed of non-metamorphosed ultramafic rocks, which from bottom up are represented by a 10-100 meter thick basal zone of quartz-bearing norite and gabbronorite, harzburgite $(100-200 \mathrm{~m})$, alternating harzburgite and orthopyroxenite $(250-400 \mathrm{~m})$, orthopyroxenite (300-700 m) with chromitite lenses (Mt. Kumuzh'ya) and 1-5 meter thick Cu-Nibearing dunite-harzburgite layers (Mt. Sopcha, "330 horizon"). The total thickness of the NKT intrusion expands southwards from 200 to $1000 \mathrm{~m}$ and culminates at Mt. Sopcha (1600 m).

The southeastern part of the Monchepluton (NPV: Mts. Nyud, Poaz and Vurechuaivench) consists mainly of 100-600 meter thick mafic rocks: basal quartz- bearing gabbronorite and norite (up to $50 \mathrm{~m}$ ), melanocratic norite with lenses of olivine-bearing harzburgite and norite, ore-bearing "critical horizon" with xenoliths, olivine-free mesocratic and leucocratic norite and gabbronorite, gabbronorite, leucogabbro, anorthosite with PGE mineralization (Mt. Vurechuaivench).

Both parts of the Monchepluton (NKT and NPV chambers) have a trough-like shape with a near-horizontal floor and flanks dipping southwestwards at an angle of $20-40^{\circ}$. The Complex is underlain by the Archaean gneiss and migmatite, and overlain by the Sumi rocks of the ImandraVarzuga rift (near Mt. Vurechuaivench). The intrusive rocks of the Monchepluton are cut by veins of basic to intermediate pegmatites and diorite, and by dolerite and lamprophyre dykes.

The syngenetic disseminated $\mathrm{Cu}-\mathrm{Ni}$ ore occurs in layers and is usually spatially confined to the layers of olivine-bearing rocks. The ore location is controlled by the primary structural elements of the intrusions. It also may be found in the upper and basal parts of the intrusions. The mineralization is related to the coarse-grained pegmatoid rocks. Occurrences of syngenetic and nest-disseminated ore with bedded, lens-shaped and stock-like forms are locally confined to the 
parts of the intrusions where fine-grained and irregular-grained rocks, pegmatoids and rocks allogenic to the intrusion ("critical horizon") are widely developed. The distribution of the two lastmentioned rock varieties may in some cases serve to reveal ore-controlling zones. Exploitable $\mathrm{Cu}$ Ni-PGE deposits of veined epigenetic ores in the Monchepluton are confined to the systems of steeply dipping shear fractures trending north-northeast and dipping south-southeast, which trace the primary structural elements of the intrusion (geometry of intrusive blocks, primary jointing etc.). The main ore-controlling elements in the occurrences of epigenetic stringer-disseminated ores are the zones of tectonic dislocations marked by schistose and blastomylonitized rocks. Most favourable for the concentration of injected stringer-disseminated ores are the places where the tectonic zones pass along the bend of the contact between rocks sharply different in physicomechanical properties, e.g. between ultramafic rocks and Archaean granite-gneiss. The epigenetic sulphide $\mathrm{Ni}-\mathrm{Cu}$ ores of the complex tend to occur in bodies with a mainly northeast strike and southwest plunge.

The rocks of the Monchepluton were dated earlier by the U-Pb methods on zircons and baddeleyite at the Geological Institute KSC RAS (Bayanova, 2004) and at the Royal Ontario Museum laboratory in Canada (Amelin et al., 1995) with a good convergence of results (see below). These ages fall in the range of 2507-2490 million years and favour the correlation of the Monchepluton mafic-ultramafic layered series with the mafic layered series of the second intrusive phase of the Fedorovo-Pansky massif. In both intrusions, the main phase melts have produced $\mathrm{Cu}-$ Ni-PGE economic mineralization where base metals constitute the major part, but the portion of platinum in the PGE disseminated occurrences is at least $20 \%$. The ore bodies within the ultramafic rocks of the Monchepluton (Papunen \& Gorbunov et al., 1985) are considerably richer than those of the Fedorov block deposit (Schissel et al., 2002). However, the deposits of the Monchegorsk region have already been mined out, while the Fedorovo-Pansky Complex is now being carefully investigated for future development.

Great areas of the Monchegorsk ore region are occupied by amphibolite-facies high-pressure garnet-bearing gabbronorite-anorthosite and anorthosite with numerous conformable and cutting veins of leucogabbro and pegmatoid rocks. These are the intrusions of the Main Ridge and LaplandKolvitsa granulite belts (Pyrchin etc.) located within strongly metamorphosed country rocks.

The rocks of the intrusions are insufficiently studied by modern geological and petrological methods, but have been investigated by mining companies because of the presence of high PGE and V-Ti concentrations. The Monchetundra intrusion is separated from the Monchepluton by a thick (a few hundreds of meters) blastomilonite zone with a garnet-amphibole mineral association (Smolkin et al., 2004). Regional shear zones cut and transform the primary monolith-like shape of the intrusion composed of roughly layered leucocratic mafic rocks. This results in a lens-like morphology of the intrusions.

Available $\mathrm{U}-\mathrm{Pb}$ isotope ages of these anorthosites fall in a wide time interval (Bayanova, 2004; Mitrofanov \& Nerovich, 2003). The zircons derived from magmatic plagioclase yield an age 
varying from 2500 to $2460 \mathrm{Ma}$ for different intrusions. A few generations of metamorphic zircons yield an age of multistage metamorphism that took place 2420, 1940 and 1900 Ma (Mitrofanov \& Nerovich, 2003).

\section{The Imandra lopolith}

The Imandra lopolith is represented by a chain of six isolated sheet-like bodies with a thickness of up to $3 \mathrm{~km}$ that extend for tens of kilometers. These are Mt. Devich'ja, Yagel'naya and Bol'shaya Varaka, Monchepoluostrov, Prikhibin'je and Umbarechka.

The Imandra lopolith cuts the Archaean biotite-amphibole gneiss and amphibolite basement rocks, as well as the volcano-sedimentary rocks of the Palaeoproterozoic Strelna Series of the Imandra-Varzuga palaeorift. The northern part of the lopolith occurs among the Strelna Series rocks, nearly conformably to the horizon of the Seidorechka felsic volcanic rocks. The southern part is sandwiched between the Palaeoarchaean amphibolites and felsic volcanic rocks of the Proterozoic Tominga Series. The intrusive relationships between the lopolith and country rocks are manifested in the recrystallization and formation of hornfels at the exocontact zone, and in the presence of schist and effusive xenoliths in the lopolith rocks. The Imandra lopolith is cut by dykes of varying composition.

The composite section of the lopolith includes the lower, the main, the upper and the roof zones. The lower layered zone has a thickness of 100 to $200 \mathrm{~m}$. At the contact with the country rocks, there is a 5-7-m thick layer of fine-grained mesocratic metamorphosed gabbroids that evidently represent the marginal part of the lopolith. Above this there are alternating plagioclasebearing orthopyroxenite and poikilitic melanocratic norite and gabbronorite with a thickness of 45$60 \mathrm{~m}$. The rocks contain up to $1-\mathrm{m}$ thick seams composed of mesocratic gabbro associated with chromite mineralization. The upper part of the lower layered zone $(45-55 \mathrm{~m})$ consists of gabbronorite.

The main zone is dominated by mesocratic gabbronorite with a thickness of about $2 \mathrm{~km}$. In the lower part of the main zone there are thin (0.1-0.4 m) seams of olivine-bearing gabbronorite, and in the upper - seams of leucocratic gabbronorite of varying thickness.

The upper layered zone (ca. $300 \mathrm{~m}$ ) displays rhythmic layering resulted from the alternation of mesocratic and leucocratic gabbro.

The roof zone ranges from 150 to $500 \mathrm{~m}$ in thickness and is composed of mesocratic quartz gabbro and gabbro-diorite. Disseminated Ti-magnetite mineralization is confined to the bottom of the zone. The upper contact of the lopolith has not been established (Bayanova \& Balashov, 1995; Bayanova et al., 2001).

In composition (pyroxenite, norite, gabbro, quartz gabbro-diorite, and anorthosite) the V-TiFe mineralization of the Imandra lopolith is similar to that of the Porttivaara block of the Koillismaa layered igneous complex in Finland (Iljina \& Hanski, 2005). 


\section{U-Pb (TIMS) method}

Following the method proposed by T. Krogh (1973), the samples were dissolved in strong (48\%) hydrofluoric acid at a temperature of $205-210^{\circ} \mathrm{C}$ over one to ten days. In order to dissolve fluorides the samples were reacted with $3.1 \mathrm{~N} \mathrm{HCl}$ at a temperature of $130^{\circ} \mathrm{C}$ during for $8-10$ hours. To determine the isotope composition of lead and concentrations of lead and uranium, the sample was divided into two aliquots in $3.1 \mathrm{~N} \mathrm{HCl}$, and a mixed ${ }^{208} \mathrm{~Pb}+{ }^{235} \mathrm{U}$ tracer was added. $\mathrm{Pb}$ and $\mathrm{U}$ were separated on an AG 1 x 8, 200-400 mesh anion exchanger in Teflon columns. The laboratory blank for the whole analysis was less than 0.1-0.08 $\mathrm{ng}$ for $\mathrm{Pb}$ and 0.01-0.04 $\mathrm{ng}$ for $\mathrm{U}$. All isotopic determinations for zircon and baddeleyite were made on Finnigan MAT-262 and MI 1201-T mass spectrometers and the $\mathrm{Pb}$ isotopic composition was analysed on a secondary-ion multiplier on a Finnigan MAT-262 in ion counting mode. The measurements of the $\mathrm{Pb}$ isotopic composition are accurate to $0.025 \%$ (Finnigan MAT-262) and 0.15\% (MI 1201-T) when calibrated against NBS SRM-981 and SRM-982 standards, respectively. The $\mathrm{U}$ and $\mathrm{Pb}$ concentrations were measured in single-filament mode with the addition of $\mathrm{H}_{3} \mathrm{PO}_{4}$ and silica gel using the method (Scharer \& Gower, 1988; Scharer et al., 1996). $\mathrm{Pb}$ and $\mathrm{U}$ concentrations were measured within the temperature ranges of $1350-1450$ and $1450-1550^{\circ} \mathrm{C}$, respectively. All of the isotopic ratios were corrected for mass discrimination during the static processing of replicate analyses of the SRM-981 and SRM-982 standards $(0.12 \pm 0.04 \%$ for the Finnigan MAT-262 and $0.17 \pm 0.05 \%$ per a.m.u.). The errors in the $\mathrm{U}-\mathrm{Pb}$ ratios were calculated during the statistical treatment of replicate analyses of the IGFM-87 standard and were assumed equal to $0.5 \%$ for Finnigan MAT-262 and 0.7\% for MI 1201-T. If the actual analytical errors were higher, they are reported in the table of isotopic data. Isochrons and sample points were calculated by the programs (Ludwig, 1991, 1999). The age values were calculated with the conventional decay constants for U (Steiger \& Jager, 1977), all errors are reported for a 2 sigma level. Corrections for common $\mathrm{Pb}$ were made according to (Stacey \& Kramers, 1975). Corrections were also made for the composition of $\mathrm{Pb}$ separated from syngenetic plagioclase or microcline if the admixture of common $\mathrm{Pb}$ was $>10 \%$ of the overall $\mathrm{Pb}$ concentration and the ${ }^{206} \mathrm{~Pb} /{ }^{204} \mathrm{~Pb}$ ratios were less than 1000 .

${ }^{143} \mathrm{Sm}^{-144} \mathrm{Nd}$ method

In order to define concentrations of samarium and neodymium, the sample was mixed with a compound tracer ${ }^{149} \mathrm{Sm} /{ }^{150} \mathrm{Nd}$ prior to dissolution. It was then diluted with a mixture of $\mathrm{HF}+\mathrm{HNO}_{3}$ (or $+\mathrm{HClO}_{4}$ ) in teflon sample-bottles at a temperature of $100^{\circ} \mathrm{C}$ until complete dissolution. Further extraction of Sm and $\mathrm{Nd}$ was carried out using standard procedures with two-stage ion-exchange and extraction-chromatographic separation using ion-exchange tar «Dowex» 50 x 8 in chromatographic columns employing $2.3 \mathrm{~N}$ and $4.5 \mathrm{~N} \mathrm{HCl}$ as an eluent. The separated $\mathrm{Sm}$ and $\mathrm{Nd}$ fractions were transferred into nitrate form, whereupon the samples (preparations) were ready for mass-spectrometric analysis. Measurements of $\mathrm{Nd}$ isotope composition and $\mathrm{Sm}$ and $\mathrm{Nd}$ concentrations by isotope dilution were performed using a multicollector mass-spectrometer in a Finnigan MAT 262 (RPQ) in a static mode using Re+Re and Ta+Re filament. The measured 
reproducibility for ten parallel analysis of $\mathrm{Nd}$ isotope composition for the standard La Jolla $=$ $0.511833 \pm 6$ was less than $0.0024 \%(2 \sigma)$. The same reproducibility was obtained from eleven parallel analyses of the Japanese standard: Ji Ndl $=0.512078 \pm 5$. The error in ${ }^{147} \mathrm{Sm} /{ }^{144} \mathrm{Nd}$ ratios of $0.2 \%(2 \sigma)$, the average of seven measures, was accepted for statistic calculations of $\mathrm{Sm}$ and $\mathrm{Nd}$ concentrations using the BCR standard. The blanks for laboratory contamination for $\mathrm{Nd}$ and $\mathrm{Sm}$ are 0.3 and $0.06 \mathrm{ng}$, respectively. Isochron parameters were developed from programs of Ludwig (1991, 1999). The reproducibility of measurements was $\pm 0.2 \%(2 \sigma)$ for $\mathrm{Sm} / \mathrm{Nd}$ ratios and $\pm 0.003 \%$ $(2 \sigma)$ for $\mathrm{Nd}$ isotope analyses. All ${ }^{147} \mathrm{Sm} /{ }^{144} \mathrm{Nd}$ and ${ }^{143} \mathrm{Nd} /{ }^{144} \mathrm{Nd}$ ratios were normalized to ${ }^{146} \mathrm{Nd} /{ }^{144} \mathrm{Nd}=0.7219$ and adjusted to ${ }^{143} \mathrm{Nd} /{ }^{144} \mathrm{Nd}=0.511860$ using the La Jolla $\mathrm{Nd}$ standard. The $\varepsilon_{\mathrm{Nd}}(\mathrm{T})$ values and model $\mathrm{T}_{\mathrm{DM}}$ ages were calculated using the currently accepted parameters of CHUR (Jacobsen \& Wasserburg, 1984): ${ }^{143} \mathrm{Nd} /{ }^{144} \mathrm{Nd}=0.512638$ and ${ }^{147} \mathrm{Sm} /{ }^{144} \mathrm{Nd}=0.1967$ and DM (Goldstein \& Jacobsen, 1988): ${ }^{143} \mathrm{Nd} /{ }^{144} \mathrm{Nd}=0.513151$ and ${ }^{147} \mathrm{Sm} /{ }^{144} \mathrm{Nd}=0.2136$.

\section{${ }^{87} \mathrm{Rb}-{ }^{86} \mathrm{Sr}$ method}

The samples and minerals were all treated with double distilled acids $\left(\mathrm{HCl}, \mathrm{HF}\right.$, and $\left.\mathrm{HNO}_{3}\right)$ and $\mathrm{H}_{2} \mathrm{O}$ distillate. A sample of 20 to $100 \mathrm{mg}$ (depending on $\mathrm{Rb}$ and $\mathrm{Sr}$ contents) was dissolved with $4 \mathrm{ml}$ of mixed $\mathrm{HF}$ and $\mathrm{HNO}_{3}(5: 1)$ in corked teflon sample-bottles and left at a temperature of about $200^{\circ} \mathrm{C}$ for a day. The solution was then divided into three aliquots in order to determine $\mathrm{Rb}$ and $\mathrm{Sr}$ isotope compositions and concentrations. These were measured by isotope dilution using separate ${ }^{85} \mathrm{Rb}$ and ${ }^{84} \mathrm{Sr}$ tracers. $\mathrm{Rb}$ and $\mathrm{Sr}$ extraction was performed by eluent chromatography with «Dowex» tar 50x8 (200-400 mesh). $1.5 \mathrm{~N}$ and $2.3 \mathrm{~N} \mathrm{HCl}$ served as an eluent. Tar volumes in the columns were $\sim 7 \mathrm{sm}^{3}$ and $\sim 4 \mathrm{sm}^{3}$. The separated $\mathrm{Rb}$ and $\mathrm{Sr}$ fractions were evaporated until dryness followed by treatment with a few drops of $\mathrm{HNO}_{3}$. Sr isotope compositions and $\mathrm{Rb}$ and $\mathrm{Sr}$ contents were measured by a MI-1201-T (Ukraine) mass-spectrometer in the two-ribbon mode using Re filaments. The samples prepared were deposited on the ribbons in the form of nitrate. Sr isotope composition in all the measured samples was normalized to a value of 0.710235 recommended by NBS SRM-987. Errors on Sr isotope analysis (confidence interval of 95\%) do not exceed 0.04\%, and those of $\mathrm{Rb}-\mathrm{Sr}$ ratio determination are of $1.5 \%$. Blank laboratory contamination for $\mathrm{Rb}$ is $2.5 \mathrm{ng}$ and for Sr $1.2 \mathrm{ng}$. The adopted Rb decay constant of Steiger and Jager (1977) was used for age calculations.

\section{Results of age determinations for the layered intrusions of the Kola Belt}

\section{Mt. General'skaya}

Samples for U-Pb dating were taken both from outcrops and from drill cores of the Mt. Generalskaya intrusion. Two samples (SA-416/1 and SA-416/2) of $150 \mathrm{~kg}$ were collected at different times from the upper gabbronorite zone at a road-side outcrop at Pechenga - Luostari which runs across the northern flank of the intrusion. The samples are taken from the lower gabbronorite zone and consist of medium-grained, massive gabbronorite, and contain relict orthoand clinopyroxenes, pseudomorphs and aggregates of hornblende and actinolite replacing pyroxene, large laths of saussuritized plagioclase and accessory Ti-magnetite. Sulphide and apatite are minor. 
An $8 \mathrm{mg}$ grain concentrate separated from the gabbronorite sample (SA 416/1) yielded two morphological types of zircons. In addition, baddeleyite was found for the first time in the layered intrusions of the Kola Peninsula (Bayanova et al., 1999).

Sample S-3464 of $200 \mathrm{~kg}$ was collected from a borehole at a depth between 600 and $800 \mathrm{~m}$ which penetrated the lower part of the layered unit. The sample is composed of slightly amphibolized meso- and leucocratic gabbronorite and of less melanocratic gabbronorite. The rocks are medium-grained, and contain bronzite, augite (rare pigeonite), andesine-labradorite, hornblende, actinolite, chlorite, biotite, apatite and Ti-magnetite.

The U-Pb age obtained on magmatic zircon (Fig. 5) from the gabbronorite is $2496 \pm 10 \mathrm{Ma}$, $\mathrm{MSWD}=1.5$; the lower intersection is at zero, indicative of modern lead loss. The zircons from the outcrop sample are more discordant than those from the drill core (Fig. 6A and Table 1).

Magmatic zircons from Sample SA-416/1 (type 1) were sent to the Royal Ontario Museum laboratory in Canada to be reanalysed in order to compare the results. The U-Pb age obtained with the use of the abrasion technique was $2505 \pm 1.5 \mathrm{Ma}$ (Amelin et al., 1995).

Zircons xenocrysts are stubby columnar and brown-pinkish crystals up to $100 \mu \mathrm{m}$ in size. They show well defined broad zones. They contain more uranium than magmatic zircons. The ${ }^{207} \mathrm{~Pb} /{ }^{206} \mathrm{~Pb}$ ages on the zircons xenocrysts ranges from $2660-2606 \mathrm{Ma}$.

Sample SA-443 of $80 \mathrm{~kg}$ is taken from the middle part of the layered unit represented by thin $(50 \mathrm{~m})$ micro-rhythms of anorthosite (or leucogabbro). The latest phase has a trough-like shape and consists of rhythmically alternating layers of melanocratic and mesocratic gabbronorites which are 3-20 $\mathrm{cm}$ and 30-80 $\mathrm{cm}$ thick respectively. The base of the micro-rhythmic zone contains an up to $4.0 \mathrm{~m}$ thick lens-like anorthosite layer. The anorthosite is replaced by slightly amphibolised leucocratic gabbronorite along strike. The layer has sharp boundaries and includes pseudobrecciated fragments of mesocratic gabbronorite at its base. Thin anorthosite apophyses penetrate the underlain gabbronorite and indicate later crystallization of the anorthositic melt.

The anorthosite is dominated by tabular plagioclase, with minor amphibole, relict intercumulus pyroxene, chlorite, biotite and apatite. Co-existing ortho- and clinopyroxenes, pigeonite, and plagioclase of labradorite composition are common.

Two zircon types (magmatic and xenocrysts) were separated from the anorthosite sample. Magmatic zircons are transparent bipyramidal-prismatic grains up to $150 \mu \mathrm{m}$ in size. The terminations of bipyramids have simple faces. In immersion view, all the grains display narrow zoning towards the crystal edge.

Three zircon populations differing mainly in size were separated for $\mathrm{U}-\mathrm{Pb}$ dating. The $\mathrm{U}-\mathrm{Pb}$ age on magmatic zircons from the anorthosite is $2446 \pm 10 \mathrm{Ma}, \mathrm{MSWD}=0.003$ (Fig. $6 \mathrm{~B}$ and Table 1).

\section{Fedorovo-Pansky Complex}

Several large samples were selected for the U-Pb dating of the Fedorovo-Pansky Complex. 
A 60-kg sample of medium- and coarse-grained gabbronorite was collected from the Lower Layered Horizon in the Eastern Kievey area. The separated zircons are transparent with a vitreous luster. All the grains were divided into three types: Pan-1 - regular bipyramidal-prismatic crystals of up to $120 \mu \mathrm{m}$; Pan-2 - fragments of prismatic crystals; Pan-3 - pyramidal apices of crystals of 80-100 $\mu \mathrm{m}$. In immersion view, all the zircons display a simple structure with fine zoning and cross jointing (Fig. 5).

The discordia plotted on three points yields the upper intersection with the concordia and the $\mathrm{U}-\mathrm{Pb}$ age at $2491 \pm 1.5 \mathrm{Ma}, \mathrm{MSWD}=0.05$. The lower intersection of the discordia with the concordia is at zero and reflects modern lead losses (Fig. 7A and Table 2). The same zircon sample was analysed in the Royal Ontario Museum laboratory (Canada); the obtained U-Pb zircon age is 2501.5 \pm 1 . $7 \mathrm{Ma}$ (Amelin et al., 1995) that is somewhat older than ours. The age obtained is interpreted as the time of crystallization of the main gabbronorite phase rock (Mitrofanov et al., 1997; Mitrofanov \& Bayanova, 1999).

Sm-Nd dating on ortho- and clinopyroxene, plagioclase and whole rock minerals extracted from the same gabbronorite gave an age of $2487 \pm 51 \mathrm{Ma}, \mathrm{MSWD}=1.5$ (Balashov et al., 1993).

Three zircon populations of prismatic habit and light-yellow colour were separated from PGEbearing gabbro-pegmatite (LLH). The zircons from Sample P-8 are stubby prismatic crystals with sharp outlines, about $100 \mu \mathrm{m}$ in size. The crystals show cross cracks and apparent zoning in immersion view. The zircons from Samples D-15 and D-18 are multi-zoned pinkish fragments of prismatic crystals with adamantine luster and they are 80 and $100 \mu \mathrm{m}$ in size. The U-Pb zircon age of $2470 \pm 9$ Ma, MSWD=0.37 (Fig. 7A and Table 2) was obtained from three points: one concordant and two lying in the upper part of the isochron. The lower intersection of the discordia with the concordia (about $300 \mathrm{Ma}$ ) indicates lead loss associated with the Palaeozoic tectonic activation of the eastern Baltic Shield and the development of the giant Khibina and Lovozero intrusions of nepheline syenites (Kramm et al., 1993). Zircons from the gabbro-pegmatite are found to have higher $\mathrm{U}$ and $\mathrm{Pb}$ concentrations than those from the gabbronorite.

Three zircon and two baddeleyite populations were separated from a sample collected from the Upper Layered Horizon in the Southern Suleypahk area. All the zircons from anorthosite are prismatic, light-pink-coloured with vitreous luster. In immersion view, they are zoned and fractured. A population of bipyramidal-prismatic zircons $(\mathrm{Pb}-1)$ is made up of elongate (3:1) crystals. Sample $\mathrm{Pb}-2$ contains zircons of round-ellipsoidal habit; and Sample $\mathrm{Pb}-3$ contains transparent flattened crystal fragments of up to $0.75 \mu \mathrm{m}$ in size.

The separated baddeleyite crystals (first recorded in the anorthosite) were subdivided into two varieties, deep-brown and brown. All the grains are fragments of transparent baddeleyite crystals of $50 \mu \mathrm{m}$ in size without selvages and inclusions.

$\mathrm{A} \mathrm{U}-\mathrm{Pb}$ isochron plotted from three zircons and two baddeleyites intersects the concordia with an age of 2447 $\pm 12 \mathrm{Ma}, \mathrm{MSWD}=2.7$ (Fig. 7B and Table 2). The lower intersection of the discordia with the concordia records recent lead loss. The position of baddeleyite points is near-concordant, 


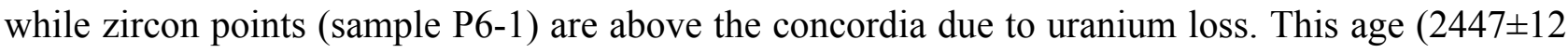
$\mathrm{Ma}$ ) is considered to constrain the origin of late-phase anorthosite, because, as shown by Heaman and LeCheminant (1993), baddeleyite is commonly generated in residual melts.

The U-Pb zircon age of the early barren orthopyroxenite from the Fedorov Block, 2526 $\pm 6 \mathrm{Ma}$, is believed to be the time of emplacement (Fig. 7C and Table 2). The U-Pb age of 2516 $7 \mathrm{Ma}$ (Fig. 7D and Table 2), obtained from zircon from barren olivine gabbro, is interpreted as the time of crystallization. The last Cu-Ni-PGE-bearing taxitic gabbronorite from the Fedorov Block (Fig. 7E

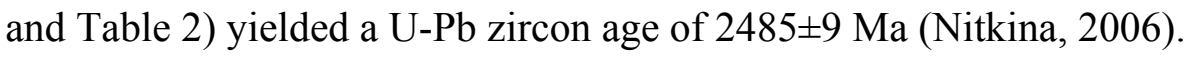

\section{Monchegorsk Layered Complex}

Ten samples of 50-120 kg were collected for U-Pb dating. Accessory baddeleyite and zircon were better preserved in drill core samples, than in outcrops (Fig. 5).

The oldest rocks studied are pegmatites of gabbronorite composition, which are associated with the ore-bearing sulphide veins from the basal zone of Mt. Travyanaya and the "critical horizon" (Mt. Hyud, Terassa deposit). Two baddeleyite and three zircon populations were examined from these rocks. All the crystals were unaltered. Baddeleyite grains are up to $80 \mu \mathrm{m}$ long and lightbrown in colour. Zircons are prismatic and isometric, up to $150 \mu \mathrm{m}$ in size, and feature narrow igneous zoning and various hues of brown. $\mathrm{U}$ and $\mathrm{Pb}$ concentrations are high, which is typical of pegmatite. A U-Pb age obtained on the five zircon and baddeleyite populations is $2500 \pm 5 \mathrm{Ma}$, $\mathrm{MSWD}=1.7$; the lower intersection of the discordia and the concordia is at $349 \pm 81 \mathrm{Ma}$, indicating Palaeozoic lead losses (Fig. 8A and Table 3). This age is comparable with that of $2493 \pm 7 \mathrm{Ma}$ obtained for gabbronorite of Mt. Nyud, and with a zircon age for the norite of Mt. Travyanaya (Fig. $8 \mathrm{~B}$ and Table 3). A U-Pb age on baddeleyite and zircon recently obtained for the coarse-grained gabbronorite of Mt. Vurechuaivench foothills (now considered as a PGE-bearing reef) is $2497 \pm 21$ Ma, being very similar to that for the Fedorovo-Pansky gabbronorite (Fig. 8C and Table 3).

To determine the age of the Sopcheozero chromite deposit located within the Dunite block of the Monchepluton, cutting dyke rocks were studied. The Dunite Block is composed of rocks poor in accessory minerals. The dykes are assumed to be associated with intrusive mafic rocks of the Monchepluton and are thought to intrude the Dunite block rocks before they had cooled. Thus the age of the dykes would constrain the minimum age limit of the Dunite Block and Sopcheozero deposit formation. For U-Pb dating a sample was collected from Borehole 1586 at a depth of 63$125 \mathrm{~m}$, from a coarse-grained gabbronorite dyke cutting the ultramafic rocks of the Dunite Block. Baddeleyite, two zircon populations and rutile were used for dating. Brown transparent plate-like baddeleyite grains of up to $70-80 \mu \mathrm{m}$ in size are well preserved. Light-pink zircons of up to $150 \mu \mathrm{m}$ in size have good outlines and thin zoning. The U-Pb age on zircon and baddeleyite is $2496 \pm 14 \mathrm{Ma}$, $\mathrm{MSWD}=0.011$; the lower intersection of the discordia with the concordia is at $313 \pm 271 \mathrm{Ma}$ (Fig. $8 \mathrm{D}$ and Table 3 ). The point for the rutile has a near concordant value of $\sim 1.84$ Ga that reflects the time of its formation. A similar U-Pb age $(2506 \pm 10 \mathrm{Ma})$ has also been obtained on zircon from a coarse-grained gabbronorite dyke from Borehole 1518 (Fig. 8E and Table 3). The gabbronorite 
dyke cuts the ultramafic rocks of the Dunite Block, therefore the Dunite Block must be older than the Monchepluton.

Small intrusions and dykes of the Monchegorsk Layered Complex were considered by most geologists to have the same age as the Monchepluton. In order to verify these relationships, diorite of the Yarva-Varaka intrusion was studied. Three zircon types and baddeleyite were selected from a sample of quartz diorite and granophyric hypersthene diorite collected in the upper part of the Yarva-Varaka section. Stubby prismatic, pink-brown zircons of up to $150 \mu \mathrm{m}$ in size were divided by their colour hues into three populations. In immersion view, they are multi-zoned. Baddeleyite grains and fragments are prismatic in habit, light-brown-coloured and up to $80 \mu \mathrm{m}$ in size. A U-Pb age obtained on four points is $2496 \pm 9 \mathrm{Ma}, \mathrm{MSWD}=0.93$, the lower intersection is at zero, indicating recent lead losses (Fig. 8F and Table 3).

The Ostrovsky intrusion also belongs to the series of small mafic-ultramafic intrusions of the Monchegorsk Layered Complex. It was considered to correlate in age with the Monchepluton and was interesting as a target for $\mathrm{Cu}-\mathrm{Ni}$ prospecting. A sample for $\mathrm{U}-\mathrm{Pb}$ dating was taken from mafic pegmatite veins in the middle part of the upper gabbronorite zone (Mt. Ostrovskaya). The pegmatite body is more than $1 \mathrm{~m}$ thick, up to $2 \mathrm{~m}$ long and has a complex morphology, with sinuous contacts with the coarse-grained slightly-amphibolized host pigeonite gabbronorite. The sample is dominated by coarse-grained to pegmatoid gabbronorites with a poikilitic texture, made up mostly of calcic plagioclase and amphibolized clinopyroxene. The $60 \mathrm{~kg}$ sample produced two types of baddeleyite and two types of zircon. Baddeleyite grains of type 1 are up to $80 \mu \mathrm{m}$ in size, with a deep-brown colour and flattened and tabular structure. Larger, up to $120 \mu \mathrm{m}$ baddeleyite grains of type 2 were found within a fringe of metamict zircon and were exposed to aeroabrasion for 15 minutes in order to remove the metamict fringe. Zircons are prismatic, up to $125 \mu \mathrm{m}$ in size, and are subdivided into light-brown and brown varieties. Zircons show well developed joints and thin zoning in immersion view. The U-Pb isochron age on two baddeleyite and two zircon points is $2445 \pm 11 \mathrm{Ma}, \mathrm{MSWD}=0.12$, the lower intersection of the discordia with the concordia is at $500 \pm 99$ Ma (Fig. $8 \mathrm{G}$ and Table 3).

To establish age correlations between the gabbronorite of the Monchepluton and the anorthosite of the Main Ridge intrusion, rock samples of the Monchetundra and Chunatundra intrusions were studied.

The Monchetundra intrusion has a complex structure and an overview of geological and geochronological investigations is given by Smolkin et al. (2004). It includes the upper zone comprised mainly of amphibolized gabbronorite and gabbro-anorthosite, and the lower zone, which consists of gabbronorite, norite and plagiopyroxenite (drilled by the deep borehole M-1).

The middle part of the upper zone, which contains a prominent horizon of slightly-altered medium-coarse-grained gabbronorite with trachytoid texture, was sampled for $\mathrm{U}-\mathrm{Pb}$ dating. The sample yielded three zircon types. Prismatic acicular crystals up to $200 \mu \mathrm{m}$ in size and their brown fragments were divided into three types by colour. In immersion view, multi-zoning, mineral 
inclusions, strong jointing, corrosion of the surface and spotted uneven grain colour are observed. The U-Pb ages (Fig. 8H-I and Table 3) on zircon from trachytoid gabbronorite are $2505 \pm 6 \mathrm{Ma}$, MSWD $=0.31$ and 2501 \pm 8 Ma, MSWD=3 (Bayanova \& Mitrofanov, 2005).

A sample was also taken from the rocks of the differentiated series of the Chunatundra intrusion. Zircons from medium-grained leucogabbro with trachytoid texture were divided into five types. Four types are up to $150 \mu \mathrm{m}$ isometric fragments of brown and pink colour, while the last fraction is represented by up to $120 \mu \mathrm{m}$ twinned pinkish-brown zircons with adamantine luster. The $\mathrm{U}-\mathrm{Pb}$ isochron plotted on five points has the upper intersection with the concordia at $2467 \pm 7 \mathrm{Ma}$, MSWD $=1.4$ and the lower intersection is at zero (Fig. 8J and Table 3). This age is close to the age obtained on magmatic zircon from anorthosite of the Pyrshin intrusion (Mitrofanov \& Nerovich, 2003) and on zircons from later anorthositic injections of the LLH (Fedorovo-Pansky Complex).

\section{Imandra lopolith}

Several large samples were taken from the different parts of the lopolith for dating. Baddeleyite was found in a chromite horizon and underlying norite of the Bol'shaya Varaka area. A sample of up to $350 \mathrm{~kg}$ collected in order to study chromite mineralization, produced about $10 \mathrm{mg}$ of zircon-baddeleyite concentrate. Angular and prismatic baddeleyite fragments were up to $80 \mu \mathrm{m}$ in size; they are black and nearly opaque and have gouges on their faces (Fig. 5). The U-Pb isochron plotted on three points has the upper intersection with the concordia at $2446 \pm 39 \mathrm{Ma}$, MSWD $=5.1$. The lower intersection is at zero reflecting recent lead loss (Fig 9A and Table 4). The best-preserved and undisturbed U-Pb system was displayed by a zircon grain with a coordinate lying on the concordia within the determination error. The coordinate of one of the baddeleyite points is strongly discordant, while the other baddeleyite point lies above the concordia due to lead removal. The baddeleyite fraction was exposed to acid treatment in order to remove a thin white coating, following a similar technique to that applied to baddeleyite from carbonatites of the Phalaborwa intrusion in South Africa (Reischmann, 1995). The U-Pb age on zircon and baddeleyite of $2446 \pm 39 \mathrm{Ma}$ is the oldest for the Imandra lopolith (Table 5).

A gabbronorite sample was taken from Borehole No 6 within the depth interval of 57.8-75.5 $\mathrm{m}$ in the Umbarechka Block of the intrusion. The mineral Sm-Nd isochron corresponds to an age of $2444 \pm 77 \mathrm{Ma}$ at $\varepsilon_{\mathrm{Nd}}=-2.0 \pm 0.6, \mathrm{MSWD}=0.31$. Zircons separated from the sample were analysed at the Royal Ontario Museum laboratory in Canada (Amelin et al., 1995), where a U-Pb age of $2441 \pm 1.6$ Ma was obtained (Table 5). The two ages determined by different systems give a good correlation and reflect crystallization time for the early rocks of the lower part of the lopolith - ca. $2.46 \mathrm{Ga}$, which we refer to the main phase intrusion.

A close $\mathrm{U}-\mathrm{Pb}$ age on zircon and baddeleyite was obtained for norite of the main phase of the Umbarechka intrusion. Three zircon points and baddeleyite lie on the isochron and give an age of $2437 \pm 7 \mathrm{Ma}$ (Fig. 9B and Table 4). Thus, the analysed rocks of the main phase of the Imandra lopolith formed within the interval of 10 million years, i.e., from 2446 to 2437 Ma. 
The second phase of the lopolith represented by leucogabbro-anorthosite and ferrogabbro with Ti-magnetite mineralization was studied in the Prikhibin'je and Bol'shaya Varaka Blocks at the upper contact of the lopolith, where one may observe a 400-m thick ferrogabbro zone with 10-m anorthosite and Ti-magnetite gabbro, and a 400-m granophyric zone. The ferrogranophyre contains up to $64 \% \mathrm{SiO}_{2}$ and up to $15 \%$ of total iron oxide, and has high contents of $\mathrm{P}_{2} \mathrm{O}_{5}, \mathrm{Co}$ and $\mathrm{Cu}$. The granophyre is close to the roof rhyodacite in silica content, total iron oxide, $\mathrm{Zr}$ and REE (Bayanova et al., 2001).

Baddeleyite was found in thin-sections of granophyre for the first time. Baddeleyite grains are brown, up to $100 \mu \mathrm{m}$ in size and form single crystals and growths with ilmenite in plagioclase, pyroxene and later quartz and biotite interstices. Single crystals are confined to aggregates of biotite, which is genetically related to an early magmatic phase in the granophyric rocks. In all cases the baddeleyite and ilmenite were earlier minerals than quartz and micropegmatite. This suggests that they oridinated during the early stages of crystallization of the intercumulus melt under conditions of low silica activity. Zircon forms individual crystals and thin fringes $(\leq 10 \mu \mathrm{m})$ around baddeleyite, which together with titanite, develop after ilmenite and are affected by subsolidus alteration. Multi-zoned light-coloured stubby prismatic zircon crystals up to 100-200 $\mu \mathrm{m}$ in size form aggregates in the micropegmatite matrix (Bayanova, 2006).

Three baddeleyite populations of flattened transparent brown about $100 \mu \mathrm{m}$ large crystals were separated from a $20 \mathrm{~kg}$ anorthosite sample. The U-Pb age obtained on these baddeleyites is $2437 \pm 11 \mathrm{Ma}, \mathrm{MSWD}=1.7$ (Fig. 9C and Table 4).

We consider that the granophyric rocks resulted from remelting of host volcano-sedimentary rocks along with a contamination by a felsic material. A 35-meter thick layer of newly-formed hybrid ferrodiorite melt gave rise to ferrogranophyric rocks. This conclusion is supported by similar $\mathrm{U}-\mathrm{Pb}$ crystallization ages obtained for the rocks from the apex of the Imandra lopolith $(2437 \pm 11$ Ma) and for the granophyres from its endocontact zone (2434 \pm 15 Ma) (Table 5) (Bayanova \& Balashov, 1995). The roof granophyres of the Bushveld complex that originated from reworking of the host felsic rocks show similar relationships (Eules \& Cawthorn, 1995).

The rocks of the lower layered part of the Imandra lopolith are cut by monzodiorite dykes, which are part of a third phase of emplacement (Bayanova et al., 2001). A $50 \mathrm{~kg}$ sample from a monzodiorite dyke cutting the Umbarechka Block yielded well-preserved accessory zircons. Light, pale pink and pinkish transparent zircon grains have prismatic habit are about $100 \mu \mathrm{m}$ in size, and display a thin faint zoning; they were subdivided into four types by colour. The $\mathrm{U}$ and $\mathrm{Pb}$ contents in the accessory minerals from the dyke are were higher than those in zircon and baddeleyite from the Imandra lopolith.

The $\mathrm{U}-\mathrm{Pb}$ isochron plotted on four varieties of zircon from the monzodiorite dyke gives an age of $2398 \pm 21 \mathrm{Ma}, \mathrm{MSWD}=2.4$; the lower intersection is at zero, suggesting modern lead losses (Fig. 9D and Table 4). A close U-Pb age was obtained for zircon and baddeleyite from a pegmatoid 
olivine gabbronorite dyke. Three zircon types and baddeleyite yield a U-Pb age of $2395 \pm 5 \mathrm{Ma}$, MSWD $=0.63$ (Fig. 9E and Table 4).

Hence, dating of different parts of the Imandra lopolith makes it possible to determine the duration of crystallization processes and define three pulses of the Imandra lopolith evolution lasting for about 50 million years. The interval agrees with the available data for the older Fedorovo-Pansky, Mt. General'skaya and Monchegorsk layered complexes.

\section{Discussion}

\section{Specific features of the isotope investigation of the intrusions}

$\mathrm{U}-\mathrm{Pb}$ (TIMS), Sm-Nd, and Rb-Sr methods have been applied in this work for different purposes.

The U-Pb concordia and isochron method has been used to define the age of the rocks. The values obtained on zircons and baddeleyites from the same sample usually lie at the isochron (Fig. 7, 8 and 9), indicating a similar age of magma crystallization and subsequent transformations. Coordinates of baddeleyites are near the concordia line. The method however encounters the obstacle that mafic rocks contain very few zircon and baddeleyite grains. Samples of tens of kilograms yield only a few milligrams of these minerals.

The samples of gabbronorite and anorthosite taken from Mt. Generalskaya and from the underlying granite-gneiss contain both magmatic and zircon xenocrysts. Refractory zircon xenocrysts reflect local processes of crustal contamination and lie outside the isochron (Fig. 6) showing a ${ }^{207} \mathrm{~Pb} /{ }^{206} \mathrm{~Pb}$ age of more than $2.6 \mathrm{Ga}$.

In order to compare our $\mathrm{U}-\mathrm{Pb}$ results (23 isochron points), some samples were sent to the Royal Ontario Museum laboratory (Canada). The data obtained there (Amelin et al., 1995) agree with ours within error (Table 5).

The Sm-Nd system is not an accurate geochronometer $(\sim 2-5 \%)$. However, the $\mathrm{Sm}-\mathrm{Nd}$ isochron method can allow the establishment of crystallization times for mafic rocks on major rock-forming minerals (olivine, orthopyroxene, clinopyroxene, and plagioclase). It is especially important for dating rocks with syngenetic ore minerals. For example, this method has been used to determine for the first time the age $(2482 \pm 36 \mathrm{Ma})$ of the early ore body in the Fedorovo-Pansky CuNi-PGE deposit of the Kola Peninsula that has economic importance (Serov et al., 2007).

For the mafic-ultramafic intrusions of the Kola belt, the Sm-Nd ages (16 points, Tables 5 and 6) overlap because of high errors, but are commonly close to the U-Pb (TIMS) data on zircon and baddeleyite. They are especially valid for the marginal fast-crystallizing rocks of the Taxitic Zone of the Fedorovo-Pansky Complex, where the early barren orthopyroxenite and gabbro have the following ages: $2521 \pm 42 \mathrm{Ma}$ and $2516 \pm 35 \mathrm{Ma}$ (Sm-Nd method) and $2526 \pm 6 \mathrm{Ma}$ and $2516 \pm 7 \mathrm{Ma}$ $(\mathrm{U}-\mathrm{Pb}$ method) respectively. The ore-bearing norite of the Fedorov block yielded an age of $2482 \pm 36$

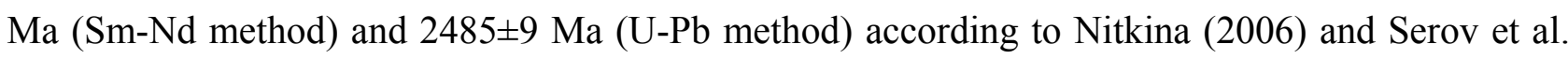
(2007) (Fig. 7 and 10). 
It is also important to stress that the $\mathrm{Sm}-\mathrm{Nd}$ method provides valuable petrological and geochemical markers: $\varepsilon_{\mathrm{Nd}}(\mathrm{T})$ and $\mathrm{T}_{\mathrm{DM}}$. The $\varepsilon_{\mathrm{Nd}}$ shows the degree of mantle magma source depletion, while $\mathrm{T}_{\mathrm{DM}}$ indicates an approximate age of the mantle protolith (Faure, 1986).

The paper presents $37 \varepsilon_{\mathrm{Nd}}$ values (Tables 5, 6, 8, and 9) and $24 \mathrm{~T}_{\mathrm{DM}}$ measurements (Tables 6, 8 , and 9) calculated from new data collected, and from previously published materials (Tolstikhin et al., 1992; Amelin \& Semenov, 1990; Huhma et al., 1990; Hanski et al., 2001).

The $\mathrm{Rb}-\mathrm{Sr}$ whole rock and mineral isochron method is mostly valuable for dating unaltered felsic igneous rocks and metamorphic amphibolite-facies associations (Faure, 1986). In our work, $10 \mathrm{Rb}-\mathrm{Sr}$ isotope values for the rocks (Table 9) are considered to have only a petrological implication. Together with specific trace elements $\left(\mathrm{Cu}, \mathrm{Ni}, \mathrm{Ti}, \mathrm{V}\right.$, and LREE), $\varepsilon_{\mathrm{Nd}}(2.5 \mathrm{Ga}), \mathrm{REE}$ (Fig. 11, Table 7), and ${ }^{4} \mathrm{He} /{ }^{3} \mathrm{He}$ (Table 10) data, the values of initial ${ }^{87} \mathrm{Sr} /{ }^{86} \mathrm{Sr}\left(\mathrm{I}_{\mathrm{Sr}}[2.5 \mathrm{Ga}]\right)$ indicate an enriched mantle reservoir 2.5 billion years ago which is comparable with the modern EM-I.

\section{The timing, pulsation, and total duration of magmatic activity}

The largest and richest ore deposits of the Monchepluton and Fedorovo-Pansky Complexes have been carefully studied by geochronological methods.

The layered or differentiated series of mafic-ultramafic rocks, from troctolite to leucogabbroanorthosite, and syngenetic $\mathrm{Cu}-\mathrm{Ni}$-PGE ores of the Monchepluton formed within the time interval of 2516 (max) to $2476(\mathrm{~min}) \mathrm{Ma}$. Without analytical errors, the time interval is from $2507 \mathrm{Ma}$ to $2493 \mathrm{Ma}$ (Table 5). Some researchers (Smolkin et al., 2004) suggest that the Vurechuaivench part of the pluton, composed of gabbroids and anorthosites containing PGE deposits, is an independent magma chamber and that the age of rock and syngenetic PGE ore emplacement is $2497 \pm 21 \mathrm{Ma}$.

The Fedorov Block of the Fedorovo-Pansky Complex represents an independent magma chamber, the rocks and ores of which differ significantly from those of the Western Pansky Block (Schissel et al., 2002). The 2-km thick rock sequence, from the Marginal Zone to the Lower Gabbro Zone (Figs. 2 and 3), is a layered or differentiated syngenetic series of relatively melanocratic pyroxenite-norite-gabbronorite-gabbro dated at 2526 \pm 6 and $2516 \pm 7$ Ma. The Taxitic Zone is penetrated by concordant and cutting Cu-Ni-PGE-bearing gabbronorite (Fedorovo deposit) of the second pulse of magmatic injection, which is slightly younger (2485 \pm 9 Ma; Table 5, Fig. 7).

The Western Pansky Block from the Main Gabbronorite Zone, without the Lower Layered Horizon and probably without the upper part (above 3000 m, Fig. 3), can also be considered a single syngenetic series of relatively leucocratic, mainly olivine-free gabbronorite-gabbro crystallized within the interval of 2503-2498-2491 $\pm 5 \mathrm{Ma}$ (Fig. 3). In the lower part of the Block there are Norite and Marginal Zones (Fig. 2). The Marginal Zone contains poor disseminated Cu-Ni-PGE mineralization. This rock series can be correlated with certain parts of the Monchepluton and the Fedorov Block. The 40-80 m thick Lower Layered Horizon (LLH) is prominent because of its contrasting structure with predominant leucocratic anorthositic rocks. The exposed part of the horizon strikes for almost $15 \mathrm{~km}$ (Fig. 2) and can be traced in boreholes down to a depth of $500 \mathrm{~m}$ (Mitrofanov et al., 2005). By its morphology, the horizon seems to be part of a single layered series. 
Nevertheless, there are anorthositic bodies that in outcrops show cutting contacts and apophyses (Latypov \& Chistyakova, 2000); the cumulus plagioclase compositions in the rocks of the horizon are different from those in the surrounding rocks (Fig. 3); and the age of the PGE-bearing leucogabbro-pegmatite, which is rather precisely defined by concordant and near-concordant U-Pb data on zircon as $2470 \pm 9$ Ma (Fig. 7A, Table 2), is slightly younger than the ages of the surrounding rocks (e.g., 2491 $\pm 1.5 \mathrm{Ma}$ ). The LLH rocks, especially the anorthosite and the PGE mineralization, probably represent an independent magmatic pulse.

The upper part and olivine-bearing rocks of the Western Pansky Block and the anorthosite of the Upper Layered Horizon (ULH) with the Southern PGE Reef (Figs. 2, 3) have been poorly explored. They differ from the main layered units of the Block in rock, mineral and PGE mineralization composition (Mitrofanov et al., 2005). Until now, there has been obtained only one reliable U-Pb age (2447 $\pm 12 \mathrm{Ma})$ for the PGE-bearing anorthosite of the block, which may represent another PGE-bearing magmatic pulse.

The early magmatic activity about $2.5 \mathrm{Ga}$ manifested itself in the gabbronorite of the Monchetundra (2505 \pm 6 Ma and 2501 \pm 8 Ma; Fig. 8H, J) and Mt. Generalskaya (2496 \pm 10 Ma; Fig. $6 \mathrm{~A})$. The magmatic activity that resulted in the formation of anorthosite took place about 2470 and

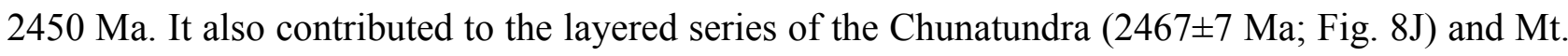
Generalskaya (2446 $\pm 10 \mathrm{Ma}$; Fig. 6B), Monchetundra gabbro (2453 \pm 4 Ma; Table 5, Mitrofanov et al., 1993), and pegmatoid gabbronorite of the Ostrovsky intrusion (2445 \pm 11 Ma; Fig. 8G).

The Imandra lopolith is the youngest large layered intrusion within the Kola Belt. It varies from the other intrusions of the Kola Belt both in its emplacement age and its metallogeny. There are five $\mathrm{U}-\mathrm{Pb}$ zircon and baddeleyite ages for the rocks of the main magmatic pulse represented by norite, gabbronorite, leucogabbro-anorthosite, gabbrodiorite, and granophyre; all formed within the interval from 2445 to $2434 \mathrm{Ma}$ (Table 5).

Thus, several eruptive pulses of magmatic activity have been established in the complex intrusions of the Kola Belt, including at least four pulses (or phases) in the Fedorovo-Pansky Complex: a 2526-2516 Ma barren pulse, and three ore-bearing of 2505-2485 Ma, $2470 \mathrm{Ma}$, and 2450 Ma. For similar intrusions of the Fenno-Karelian Belt, for example, Penikat intrusion in Finland, five magmatic pulses varying only in geochemistry have been distinguished from the same deep chamber (Iljina \& Hanski, 2005).

A total duration for magmatic processes of over 80 million years in the Kola Belt intrusions is unexpected for many researchers.

The multi-phase magmatic duration of the Fenno-Karelian Belt intrusions was short-term and took place about $2.44 \mathrm{Ga}$ years ago. However, there are only a few $\mathrm{U}-\mathrm{Pb}$ precise age estimations for the Fenno-Karelian Belt intrusions (Iljina \& Hanski, 2005). A joint Russian-Finnish research collaboration intended for dating the intrusions of the both belts has recently been initiated. It is expected that the research will result in updating the knowledge about the timing and duration of the Paleoproterozoic ore-forming intrusions on the Baltic Shield. 
The Kola results underline that the layering of the intrusions with thinly-differentiated horizons and PGE reefs was not contemporaneous (or syngenetic) with each intrusion defining its own metallogentic trends in time and space.

\section{Metallogenic implications}

The Palaeoproterozoic magmatic activity in the eastern Baltic Shield is associated with the formation of widespread ore deposits: $\mathrm{Cu}-\mathrm{Ni}( \pm \mathrm{PGE}), \mathrm{Pt}-\mathrm{Pd}(+\mathrm{Rh}, \pm \mathrm{Cu}, \mathrm{Ni}, \mathrm{Au}), \mathrm{Cr}, \mathrm{Ti}-\mathrm{V}$ (Richardson \& Shirey, 2008; Mitrofanov \& Golubev, 2008).

On the Kola Peninsula, economic Cu-Ni (+PGE) deposits are known in the Monchegorsk ( $2500 \mathrm{Ma})$ and Pechenga ( $1980 \mathrm{Ma})$ type intrusions. In the Monchepluton (the Monchegorsk type), syngenetic disseminated $\mathrm{Cu}-\mathrm{Ni}(+\mathrm{PGE})$ ore bodies of magmatic origin are confined to basal parts of magmatic chambers (Papunen \& Gorbunov, 1985), while massive rich redeposited ores in the veined bodies of the Monchepluton bottom as well as beyond it (offset bodies) also contain a relatively high portion of platinum among platinum-group elements. They are associated mainly with ca. 2500 Ma magnesia-rich mafic-ultramafic rocks with $\varepsilon_{\mathrm{Nd}}(2.5 \mathrm{Ga})$ values varying from -1 to -2. In comparison, $\mathrm{Cu}-\mathrm{Ni}( \pm \mathrm{PGE})$ ores of the Pechenga type intrusions that are not discussed are related to the 1980 Ma gabbro-wehrlite rocks with $\varepsilon_{\mathrm{Nd}}(1.98 \mathrm{Ga})$ values varying from +1 to +3 (Hanski et al., 1990; Mitrofanov \& Golubev, 2008). The basal ores of the Fedorovo deposit are first of all valuable for platinum-group elements ( $\mathrm{Pt}, \mathrm{Pd}, \mathrm{Rh})$, but nickel, copper and gold are also of economic importance here (Schissel et al., 2002). The ore-forming magmatic and post-magmatic processes are closely related to the Taxitic Zone gabbronorite of $2485 \pm 9$ Ma magmatic pulse.

Pt-Pd $( \pm \mathrm{Cu}, \mathrm{Ni}, \mathrm{Rh}, \mathrm{Au})$ reef-type deposits and ore occurrences of the Vurechuaivench Foothills (Monchepluton) and Western Pansky Block (Fedorovo-Pansky Complex) seem, in terms of genesis, to be associated with pegmatoid leucogabbro and anorthosite rocks enriched in late-stage fluids. Portions of this magma produce additional injections of ca. $2500 \mathrm{Ma}$ (Vurechuaivench), ca. $2470 \mathrm{Ma}$ (the Lower, Northern PGE reef), and ca. $2450 \mathrm{Ma}$ (the Upper, Southern PGE reef of the Western Pansky Block and PGE-bearing mineralization of the Mt. Generalskaya intrusion). These nonsimultaneous injections are quite close in terms of composition, prevalence of Pd over Pt, ore mineral composition (Mitrofanov et al., 2005), and isotope geochemistry of $\mathrm{Sm}-\mathrm{Nd}$ and $\mathrm{Rb}-\mathrm{Sr}$ systems. The $\varepsilon_{\mathrm{Nd}}$ values for the rocks under consideration vary from -1 to -3 , which probably indicates a single long-lived magmatic hearth.

Chromium concentration $(>1000 \mathrm{ppm})$ is typical geochemical feature of the lower maficultramafic rocks of the layered intrusions of the Baltic Shield (Alapieti, 1982; Iljina \& Hanski, 2005). The chromite mineralization is known in the basal series of the Monchepluton, FedorovoPansky Complex, Imandra lopolith (Russia), Penikat and Narkaus intrusions (Finland) and in chromite deposits of the Kemi intrusion (Finland) and Dunite Block (Monchepluton, Russia). On the contrary, Fe-Ti-V mineralization of the Mustavaara intrusion (Finland) tends to most leucocratic 
parts of the layered series, and to leucogabbro-anorthosite and gabbro-diorite of the Imandra lopolith (Russia) and Koillismaa Complex (Finland).

Thus, PGE-bearing deposits of the region are represented by two types: the basal and the reeflike ones. According to modern economic estimations, the basal type of deposits is nowadays more preferable for mining, even if the PGE concentration (1-3 ppm) is lower compared to the reef-type deposits $(>5 \mathrm{ppm})$. Basal deposits are thicker and contain more platinum, copper and, especially, nickel. These deposits are accessible to open pit mining.

\section{Petrological and geodynamic implications}

Magmatic processes since the Palaeoproterozoic $(2.53 \mathrm{Ga})$ have affected almost the whole region of the East-Scandinavian (Kola-Lapland-Karelian) province and a mature continental crust formed $(2.55 \mathrm{Ga})$ in the Neoarchaean (Gorbatschev \& Bogdanova, 1993). Thick (up to $3 \mathrm{~km}$ ) basaltic volcanites of the Sumian age (2.53-2.40 Ga) in Karelia, Kola and northeast Finland cover an area of greater than $200.000 \mathrm{~km}^{2}$. In the north, magmatic analogues of these volcanic rocks are represented by two belts of layered intrusions and numerous dyke swarms (Vuollo et al., 2002, Vuollo \& Huhma, 2005). This together composes a single time- and space-related megacyclic association, the East-Scandinavian Large Igneous Province (ESCLIP). All the magmatic units of the province covering a huge area show similar geological, compositional and metallogenic features.

Regional geological settings indicate anorogenic rift-like intraplate arrangements involving volcano-plutonic belts connecting different domains of the Paleoarchaean Kola-Lapland-Karelia protocontinent. This resembles early advection extensional geodynamics of passive rifting that is typical of intraplate plume processes (Pirajno, 2007).

Geochemical and isotope-geochemical data shed light on features of deep magma source for the ESCLIP rocks. $\mathrm{T}_{\mathrm{DM}}$ values (Faure, 1986) are approximately the age of the depleted mantle reservoir $(\mathrm{DM})$ with slightly enriched $\mathrm{Sm}-\mathrm{Nd}$ ratios. The $\mathrm{T}_{\mathrm{DM}}$ values (Tables 6, 8 and 9) lie within the interval of 3.1-2.8 Ga. The $\varepsilon_{\mathrm{Nd}}$ values (Tables 5, 6, 8 and 9) vary from -1.1 to -2.4 and similar $\mathrm{I}_{\mathrm{Sr}}$ values (0.703-0.704) obtained for discrete layered intrusions form a narrow range of enriched compositions. It is difficult to argue for a local crustal contamination and we suggest that the magmas producing different rocks of the ESCLIP layered intrusions were derived from a single homogenous mantle source enriched both with typically magmatic ore elements (Ni, TI, V, and Pt) and lithophile elements including light REE (Fig. 11). To some extent, this reservoir is comparable with the modern EM-1(Fig. 13) source (Hofmann, 1997).

${ }^{4} \mathrm{He} /{ }^{3} \mathrm{He}$ ratio is also a reliable isotope tracer of mantle plume processes (Tolstikhin \& Marty, 1998; Bayanova et al., 2006; Pirajno, 2007). Their use in studying Precambrian rocks and requires special case. Table 10 shows recent helium isotope data for the rocks and minerals of the Kola Belt intrusions. The data indicate that the ${ }^{4} \mathrm{He} /{ }^{3} \mathrm{He}$ isotope ratios of $\mathrm{n} \times 10^{6-5}$ correspond to those of the upper mantle and differ from those of the crust $\left(\mathrm{n} \times 10^{8}\right)$ and lower mantle $\left(\mathrm{n} \times 10^{4}\right)$ (Tolstikhin \& Marty, 1998). The helium isotope data tend to favour a source dominated by mantle derived magmas with only local crustal contamination. 
According to the available data (Campbell, 2001; Condie, 2001; Vuollo et al., 2002; Bleeker, 2003; Ernst \& Buchan, 2003; present study), the peak of the mafic-ultramafic magmatic activity of the Kola-Karelian, Superior and Wyoming provinces has been estimated at $\sim 2.45 \mathrm{Ga}$. Figure 13 presents an attempt to demonstrate some reconstruction of the Archaean supercontinent embodying these three provinces of Europe and North America (Heaman, 1997). Insert (A) shows trends of the Kola and Fenno-Karelian Belts of 2.52-2.44 Ga layered intrusions with the intraplate nature interpreted from the results of the present study.

The ESCLIP layered intrusions are directly related to the Baltic Shield metallogeny (Mitrofanov \& Golubev, 2008). The $>80$ Ma duration and multiphase history of the Kola Belt layered mafic intrusions (i.e., 2.53- to $2.45 \mathrm{Ga}$ ) has been shown here. It has also been underlined that the younger intrusions of the Fenno-Karelian Belt (Fig. 1) cluster at $2.44 \mathrm{Ga}$ (Iljina \& Hanski, 2005). The partially asynchronous evolution of these two belts, that are thought to be arms of a mantle plume, is now being examined in more detail as a follow-up to this study within the framework of Russian-Finnish research collaboration.

\section{Summary and conclusions}

A number of new $\mathrm{U}-\mathrm{Pb}$ and $\mathrm{Sm}-\mathrm{Nd}$ isotope data were obtained for various rocks of the mafic layered intrusions of the Kola Belt (Baltic Shield), including those which bear PGE, Ni-Cu and Ti$\mathrm{V}$ mineralization. A surprisingly long period of multiphase magmatic activity, from 2530 to 2450 Ma (about 80 million years), resulted in the intrusion of large-scale ore-bearing intrusions of the Kola Belt. Magmatism continued until about 2400 Ma and generated wide-spread dykes and smallscale intrusions. These results contrast with the published data indicating short-term evolution interval ( $2440 \mathrm{Ma})$ for similar intrusions of the Fenno-Karelian Belt (Iljina \& Hanski, 2005).

The two belts of mafic layered intrusions of the Baltic Shield (the Kola and Fenno-Karelian belts), together with the surrounding volcanic rocks and dyke swarms, compose the Palaeoproterozoic East-Scandinavian Large Igneous Province (ESCLIP) with an area of more than $200.000 \mathrm{~km}^{2}$. The petrological-geodynamic interpretation proposed by the present paper of the ESCLIP is a product of a vast long-lived plume is based on the enriched isotope characteristics of the magmas and also the large volume and widespread distribution of the magmas. We acknowledge that alternatives involving super-long duration of the homogenous deep-seated magma sources are possible.

\section{Acknowledgements}

The authors would like to thank the following: L. Koval for baddeleyite and zircon separation from rock samples; E. Savchenko for baddeleyite and zircon analyses using a Cameca MS-46 and for taking images of baddeleyite crystals; N. Levkovich for the chromatographic separation of $U$ and $\mathrm{Pb}$ for analyses by mass spectrometry at the Geological Institute, Kola Science Center, Russian Academy of Sciences. 
The study was supported by the Russian Foundation of Fundamental Investigations, project no. 07-05-00956, 08-05-00324, Program no. 8 of the Division of Earth Science, Russian Academy of Sciences, and Program for leading Research Schools NSH-1413.2006.5 (headed by Acad. F.P. Mitrofanov). We thank S. Reddy who kindly provided a review of this paper and also three anonymous reviewers.

\section{References}

Alapieti, T.T. 1982. The Koillismaa layered igneous complex, Finland: its structure, mineralogy and geochemistry, with emphasis on the distribution of chromium. Geol. Surv. Finland, Bull. 319, 116.

Alapieti, T.T., Filen, B.A., Lahtinen, J.J., Lavrov, M.M., Smolkin, V.F. \& Voitekhovsky, S.N. 1990. Early Proterozoic layered intrusions in the Northeastern part of the Fennoscandian Shield. Miner. Petrol., 42, 1-22.

Amelin, Yu.V., Heaman, L.M \& Semenov, V.S. 1995. U-Pb geochronology of layered mafic intrusions in the eastern Baltic Shield: implications for the timing and duration of Palaeoproterozoic continental rifting. Precambrian Research, 75, 31-46.

Balashov, Y.A., Bayanova, T.B., \& Mitrofanov, F.P. 1993. Isotope data on the age and genesis of layered basic-ultrabasic intrusions in the Kola Peninsula and northern Karelia, northeastern Baltic Shield. Precambrian Research, 64, N 1/4, 197-205.

Bayanova T.B. Age of reference Geological complexes of the Kola region and the duration of igneous processes. Saint-Petersburg, Nauka, 174.

Bayanova, T.B, Novikov D.D., Nitkina, E.A., Serov, P.A. \& Mitrofanov, F.P. 2006. Polychronic and long-time interval of the Formation Proterozoic PGE - bearing Fedorovo-Pansky intrusion. Understanding the genesis of ore deposits to meet the demands of the $21^{\text {st }}$ century. $12^{\text {th }}$ quadrennial IAGOD symposium 2006: Abstract. Moscow. (fill №106).

Bayanova, T.B. \& Mitrofanov, F.P. 2005. Layered Proterozoic PGE intrusions in Kola region: new isotope data. X international symposium of platinum "Platinum-Group Elements - from Genesis to Beneficiation and Environmental Impact”: Extended abstracts. Oulu, Finland, 289-291.

Bayanova, T.B. 2006. Baddeleyite: A Promising Geochronometer for Alkaline and Basic Magmatism. Petrology. 14, N 2, 187-200.

Bayanova, T.B., \& Balashov, Yu.A 1995. Geochronology of Palaeoproterozoic layered intrusions and volcanites of the Baltic Shield: Proceed. of the 1 st. Intern. Barents Sympos. "Geology and minerals in the Barents Region”. Norges geol. unders. Spec. Publ. 7, 75-80.

Bayanova, T.B., Galimzyanova, R.M. \& Fedotov, G.A. 2001. Evidence of the multiphase complex history of the Imandra lopolith. Svekalapko. Europrobe project. 6th Workshop. Abstracts. Lammi, Finland. University of Oulu, 7. 
Bayanova, T.B., Smolkin, V.F. \& Levkovich, N.V. 1999. U-Pb geochronological study of Mount Generalskaya layered intrusion, northwestern Kola Peninsula, Russia. Transactions of the Institution of Mining and Metallurgy, 108, B83-B90.

Bleeker, W. 2003. The late Archaean record: a puzzle in ca. 35 pieces. Lithos. 71, 99-134.

Campbell, I.H. 2001. Identification of ancient mantle plumes. In Ernst R.E. and Buchan (Eds.) Mantle plumes: their identification through time. Geological Society of America, Special Papers. $352,5-22$.

Chashchin, V.V., Bayanova, T.B. \& Apanasevich, E.A. 2002. The Monchegorsk Ore District as an Example of the Palaeoproterozoic Ore-bearing Chamber Structure (Kola, Russia). Geology of Ore Deposits, 44, N 2, 142-149.

Coffin, M.F. \& Eldholm, O. 1994. Large igneous provinces: crustal structure, dimensions and external consequences. Rev. Geophys., 32, 1-36.

Condie, K.C. 2001. Mantle Plumes and Their Record in Earth History. Condie. Cambridge. University press, 306.

Ernst, R.E. \& Buchan, K.L. 2003. Recognizing Mantle Plumes in the Geological Record. Annu. Rev. Earth Planet. Sci., 31, 469-523.

Eules, H.V. \& Cawthorn, R.G. 1995. The Bushveld Complex. Layered Intrusions. Developments in Petrology 15. Amsterdam; N.Y., Tokyo: Elsevier, 181-229.

Faure G.1986. Principles of Isotope Geology. 2 nd eds.Wiley. New York, 460.

French, I.E., Heaman, L.M., Chacko, T., \& Sristava, R.K. 2008. 1891-1883 Ma Southern BastarCuddapah mafic igneous events, Judia: A newly recognized large igneous province. Precambrian Research, 160, 308-322.

Goldstein, S.J. \& Jacobsen, S.B. 1988. Nd and Sr isotopic systematics of river water suspended material implications for crystal evolution. Earth Plan. Sci. Letters, 87, 249-265.

Gorbatschev, R. \& Bogdanova, S. 1993. Frontiers in the Baltic Shield. Precambrian Research,V. 64, 3-21.

Hanski, E., Huhma, H., Smolkin, V. et al. 1990. The age of the ferropicric volcanics and comagmatic Ni-bearing intrusions at Pechenga, Kola Peninsula, USSR. Bull. Geol. Soc. Finland, 1990, V. 62, No 2, 123-133.

Hanski, E., Walker, R.J., Huhma, H., \& Suominen, I. 2001. The Os and Nd isotopic systematics of c. 2.44 Ga Akanvaara and Koitelainen mafic layered intrusions in northern Finland. Precambrian Research, 109, 73-102.

Heaman, L.M. \& LeCheminant, A.N. 1993. Paragenesis and U-Pb systematics of baddeleyite (ZrO). Chemical Geology. Elsevier, 110, 95-126.

Heaman, L.M. 1997. Global mafic magmatism at $2.45 \mathrm{Ga}$ : Remnants of an ancient large igneous province? Geology, 25, No 4, 299-302.

Hofmann, A.W. 1997. Mantle geochemistry: the message from oceanic volcanism. Nature, 385, 219-229. 
Huhma, H., Clift, R.A., Perttunen, V. \& Sakko, M. 1990. Sm-Nd and Pb isotopic study of mafic rocks associated with early Proterozoic continental rifting: The Perapohja schist belt in Northern Finland. Contrib. Mineral. Petrpol., 104, 369-379.

Iljina, M., \& Hanski, E. 2005. Layered mafic intrusions of the Tornio-Näränkävaara belt. In Lehtinen, M., Nurmi, P.A. \& Rämo, O.T. (Eds.). Precambrian Geology of Finland - Key to the Evolution of the Fennoscandian Shield. Elsevier B.V., Amsterdam. 101-138.

Jacobsen, S. B. \& Wasserburg, G. J. 1984. Sm-Nd Isotopic Evolution of Chondrites and Achondrites, II. Earth Planet. Sci. Lett., 67, 137-150

Kramm, U. 1993. Mantle components of carbonatites from the Kola Alkaline Province, Russia and Finland: A Nd-Sr study. Eur J. Mineral, 5, 985-989.

Krogh, T. E. 1973. A Low-Contamination Method for Hydro-thermal Dissolution of Zircon and Extraction of $U$ and Pb for Isotopic Age Determinations. Geochim. Cosmochim. Acta, 37, 485494.

Latypov, R.M. \& Chistyakova, S.Yu. 2000. Mechanism for differentiation of the Western-Pana layered intrusion. Apatity: Publ. of KSC RAS, 315. (in Russian)

Li C., Naldrett A.J. 1993. Sulfide capacity of magma: a quantitative model and its applition to the formation of sulfide ores at Sudbury, Ontario. Economic Geology. 88, 1253-1260.

Ludwig, K. R. 1999. ISOPLOT/Ex - A geochronological toolkit for Microsoft Excel, Version 2.05. Berkeley Geochronology Center Special Publication, 1a, 49.

Ludwig, K.R. 1991. PBDAT - A Computer Program for Processing Pb-U-Th isotope Data. Version 1.22. Open-file report 88-542. US Geol. Surv., 38.

Mitrofanov F., Golubev A. 2008. Russian Fennoscandia metallogeny. Abstr. To 33 IGC. Oslo, Norway.

Mitrofanov, F.P, Smolkin, V.F., Bayanova, T.B, Neradovsky, Yu.N., Ohnenstetter, D., Ohnenstetter, M. \& Ludden, J. 2002. Palaeoproterozoic (2.5-2.4 Ga) Plume Magmatism in the North-Eastern Baltic Shield and Origin of the PGE, Sulphide and Chromite Ore Deposit. Extended abstracts: $9^{\text {th }}$ International Platinum Symposium. Billings, Montana, USA, 309-311.

Mitrofanov, F.P. \& Bayanova, T.B. 1999. Duration and timing of ore-bearing Palaeoproterozoic intrusions of Kola province. Mineral Deposits: Processes to Processing. Stanley et al. (Eds.). Balkema, Rotterdam, 1275-1278.

Mitrofanov, F.P. \& Nerovich, L.I. 2003. Timming of magmatic crystallization and metamorphic transformation in the Pyrshin and Abvar Autonomous anorthosite massifs, Lapland granulate belt. 11, No 4, 343-351.

Mitrofanov, F.P., Balabonin, N.L., Bayanova, T.B. et al. 1997. Main results from the study of the Kola PGE-bearing province, Russia. Mineral Deposits. Papunen (Eds.). Balkema, Rotterdam, 483486. 
Mitrofanov, F.P., Balagansky, V.V., Balashov, Yu.A., Gannibal, L.F., Dokuchaeva, V.S., Nerovich, L.I., Radchenko, M.K. \& Ryungenen, G.I. 1993. U-Pb age for gabbro-anorthosite of the Kola Peninsula. Doklady RAN, 331, No 1, 95-98.

Mitrofanov, F.P., Korchagin, A.U., Dudkin, K.O. \& Rundkvist, T.V. 2005. Fedorovo-Pana layered mafic intrusion (Kola peninsula, Russia): Approaches, methods, and criteria for prospecting PGEs. Exploration for platinum-group elements deposits. Short Course delivered on behalf of the Mineralogical Association of Canada in Oulu, Finland, 35, 343-358.

Nitkina, E. A. 2006. U-Pb Zircon Dating of Rocks of the Platiniferous Fedorova-Pana Layered Massif, Kola Peninsula. Doklady Earth Sciences, 408, No 4, 551-554.

Papunen H. and Gorbunov G. I. (eds.). 1985. Nickel-Copper deposits of the Baltic Shield and Scandinavian Caledonides. Geological Survey of Finland, Bulletin 333, 394.

Pirajno, F. 2007. Mantle plumes, associated intraplate tectono-magmatic processes and ore systems. Episodes. 30, No 1, 6-19.

Richardson, S.H. \& Shirey, S.B. 2008 Continental mantle signature of Bushveld magmas and coeval diamonds, Nature. 453, 910-913.

Reischmann, T. 1995. Precise U-Pb age determination with baddeleyite $\left(\mathrm{ZrO}_{2}\right)$, a case study from the Phalaborwa Igneous Complex, South Africa. S. Afr. J. Geol., 1, 1-4.

Scharer, U. \& Gower, C.F, 1988. Crustal Evolution in Eastern Labrador: Constraints from Precise U-Pb Ages. Precambrian Research, 38, 405-421.

Scharer, U., Wilmart, E., \& Duchesne, J.-C. 1996. The Short Duration and Anorogenic Character of Anorthosite Magmatism: U-Pb Dating of the Rogaland Complex, Norway. Earth Planet. Sci. Lett., 139, 335-350.

Sharkov E.V., Bogatikov O.A., Grokhovskaya T.L., Snyder G.A., Taylor L.A. 1995. Petrology and $\mathrm{Ni}-\mathrm{Cu}$-Cr-PGE mineralization of the largest mafic pluton in Europe: the early Proterozoic Burakovsky Layered Intrusion, Karelia, Rossia. International Geology Reviev. 37, 509-525.

Schissel, D., Tsvetkov, A.A., Mitrofanov, F.P. \& Korchagin, A.U. 2002. Basal Platinum-Group Element Mineralization in the Fedorov Pansky Layered Mafic Intrusion, Kola Peninsula Russia. Econ. Geol., 97, 1657-1677.

Serov, P.A., Nitkina, E.A., Bayanova, T.B. \& Mitrofanov, F.P. 2007. Comparison of the new data on dating using $\mathrm{U}-\mathrm{Pb}$ and $\mathrm{Sm}-\mathrm{Nd}$ isotope methods of early barren phase rocks and basal orehosting rocks of the Pt-bearing Fedorovo-Pansky layered intrusion (Kola peninsula). Doklady Earth Sciences, 415, No 3, 1-3. (in Russian)

Skuf'in, P.K. \& Bayanova, T.B. 2006. Early Proterozoic Central-Type Volcano in the Pechenga Structure and Its Relation to the Ore-Bearing Gabbro-Wehrlite Complex of the Kola Peninsula Petrology, 14, No 6, 609-627.

Smolkin, V.F., Fedotov, Zh.A, Neradovsky, Yu.N., Bayanova, T.B. et al. 2004. Layered intrusions of the Monchegorsk ore region: petrology, mineralization, isotope features and deep structure. 
Mitrofanov, F.P. \& Smolkin, V.F. (Eds.). Part 1. Apatity: publ. by Kola Science Centre RAS, 177. (in Russian)

Stacey, J. S. \& Kramers, J. D. 1975. Approximation of Terrestrial Lead Isotope Evolution by a TwoStage Model. Earth Planet. Sci. Lett., 26, 207-221.

Steiger, R. H. \& Jager, E. 1977. Subcommission on Geo-chronology: Convention on the Use of Decay Constants in Geo- and Cosmochronology. Earth Planet. Sci. Lett., 36, 359-362.

Tolstikhin, I.N. \& Marty, B. 1998. The evolution of terrestrial volatiles: A view from helium, neon, argon and nitrogen isotope modeling. Chemical Geology, 147, 27-52.

Tolstikhin, I.N., Dokuchaeva, V.S., Kamensky, I.L. \& Amelin, Yu.V. 1992. Juvenile helium in ancient rocks: II. U-He, $\mathrm{K}-\mathrm{Ar}, \mathrm{Sm}-\mathrm{Nd}$, and Rb-Sr systematics in the Monchepluton. ${ }^{3} \mathrm{He}{ }^{A} \mathrm{He}$ rations frozen in uranium-free ultramafic rocks. Geochim. Cosmochim. Acta. 56, 987-999.

Vogel, D.C., Vuollo, J.I., Alapieti, T.T. \& James, R.S. 1998. Tectonic, stratigraphic, and geochemical comparison between ca. 2500-2440 Ma mafic igneous events in the Canadian and Fennoscandian Shields. Precambrian Research, 92, 89-116.

Vrevsky, A.B. \& Levchenkov, O.A. 1992. Geological-geochronological scale of the endogenous processes operated within the Precambrian complexes of the central part of the Kola Peninsula. In: Mitrofanov, F.P. \& Bolotov, V.I. (Eds.). Geodynamics and deep structure of the Soviet Baltic Schield. Apatity, 150. (in Russian).

Vuollo, J.I. \& Huhma, H. 2005. Palaeoproterozoic mafic dykes in NE Finland. In: Lehtinen, M., Nurmi, P.A. \& Rämö, O.T. (eds.) Precambrian Geology of Finland. Elsevier. B.V. Amsterdam, $195-236$

Vuollo, J.I., Huhma, H., Stepana, V. \& Fedotov, Zh.A. 2002. Geochemistry and Sm-Nd isotope studies of a $2.45 \mathrm{Ga}$ dyke swarm: hints at parental magma compositions and PGE potential to Fennoscandian layered intrusions. In: Boudreau, A. (ed.). $9^{\text {th }}$ Intern. Platinum Symp., 21-25 July, 2002, Billings, Montana USA, 469-470.

Yi-Gang Xu. 2007. Mantle plume, large igneous provinces and lithospheric evolution. Episodes, V. 30, No 1, 5 .

Zozulya, D. R., Bayanova, T. B. \& Nelson, E. G. 2005. Geology and Age of the Late Archaean Keivy Alkaline Province, Northeastern Baltic Shield. Geology, 113, 601-608. 


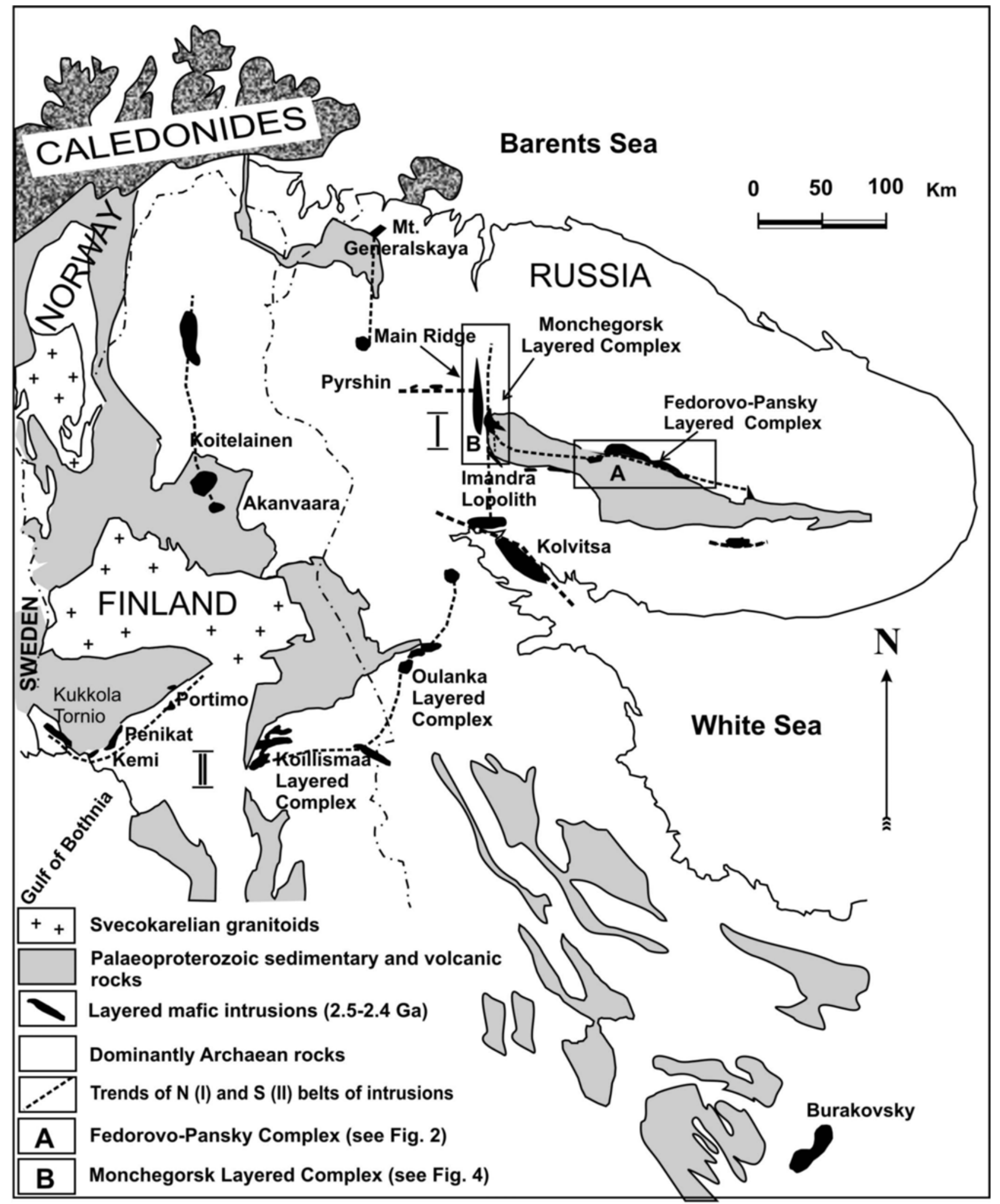

Fig.1. Generalized geological map of the northeastern part of the Baltic Shield and the location of Early Proterozoic mafic layered intrusions. 


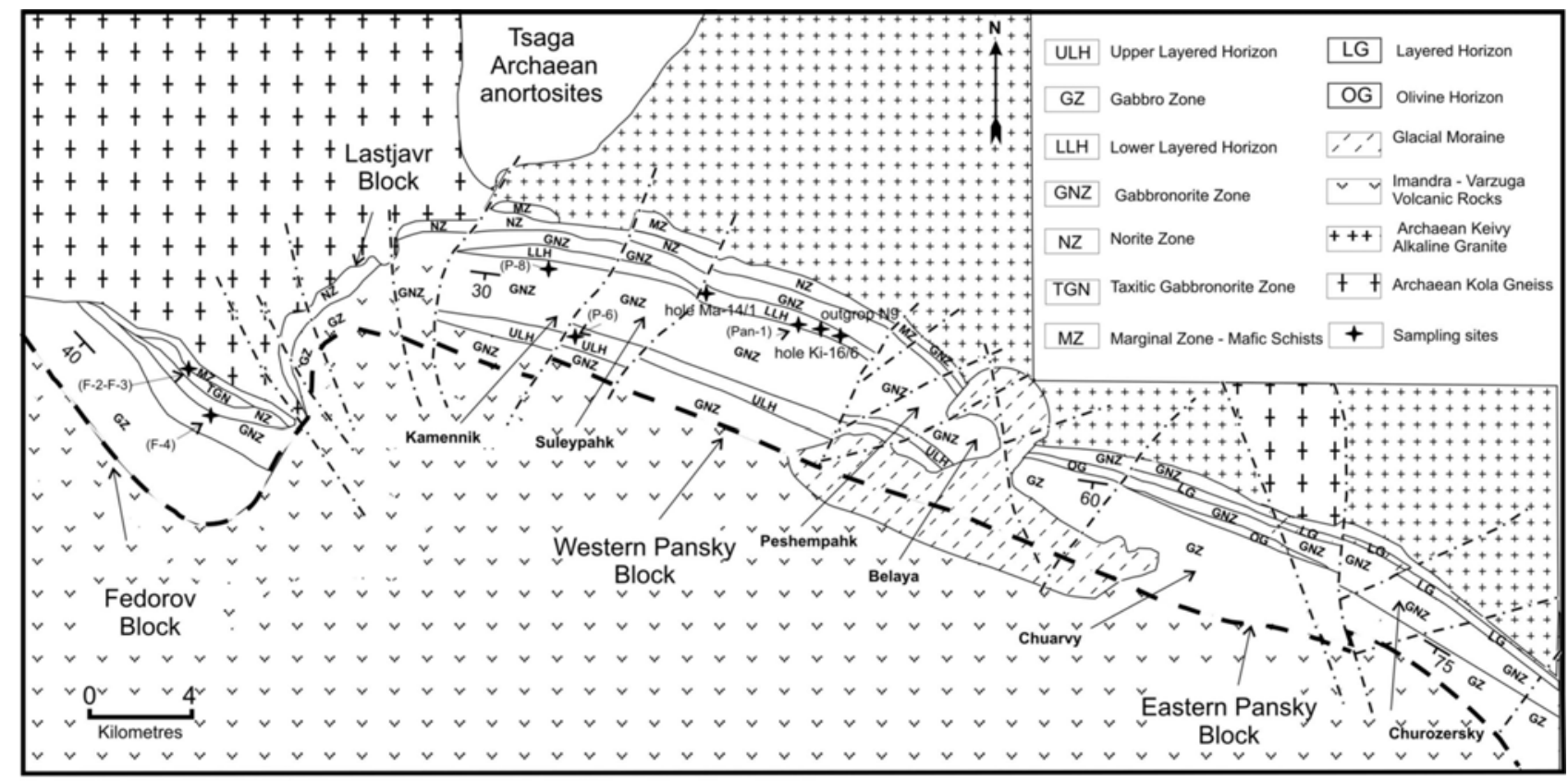

Fig. 2. General geological map of the Fedorovo-Pansky Layered Complex (from Mitrofanov et al., 2005). 


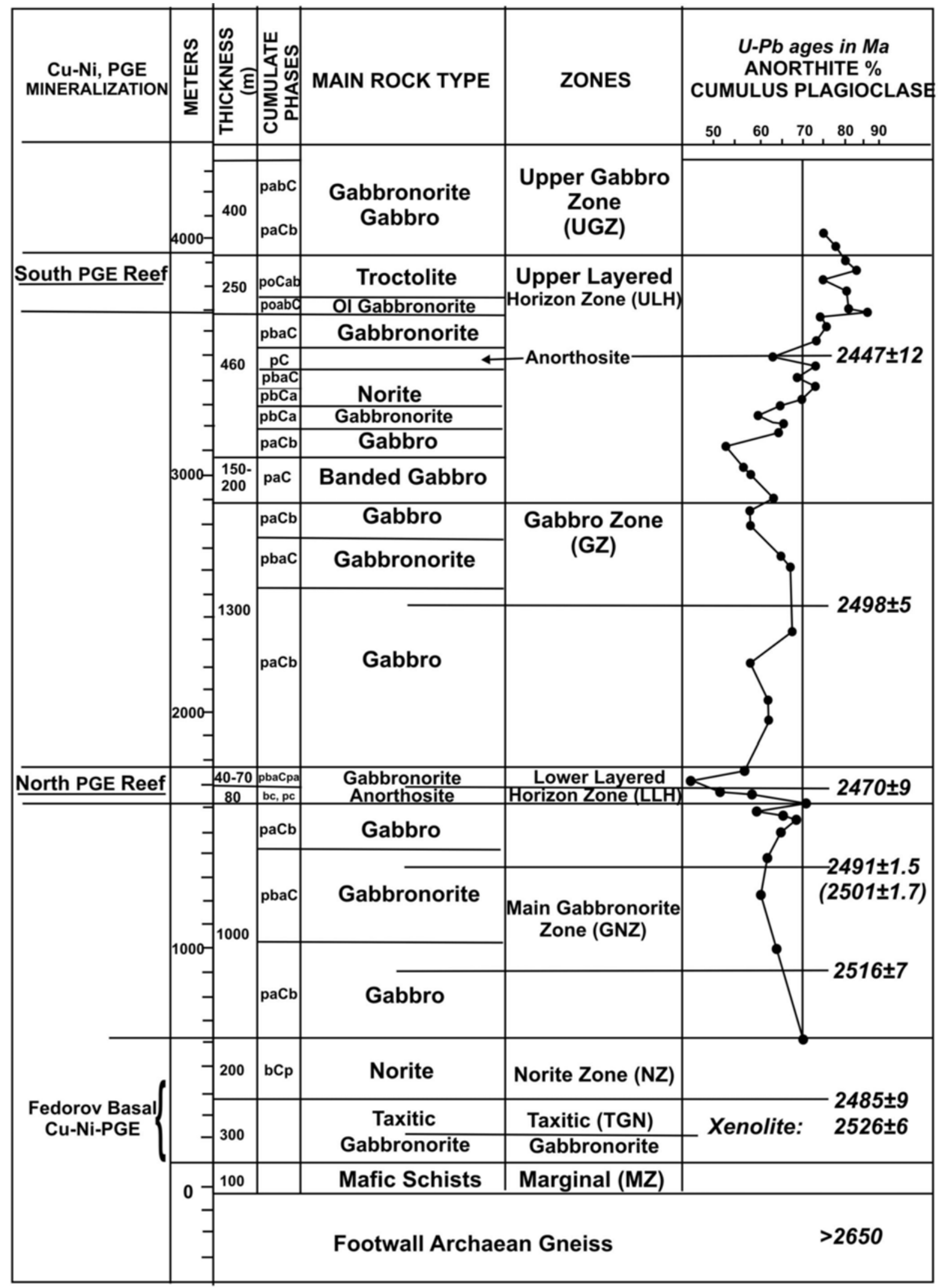

Fig. 3. Composite "stratigraphic" section of the Fedorovo-Pansky Complex with Cu-Ni and PGE mineralization (modified after Schissel et al., 2002). The cumulate mineral terminology used in this paper is that of cumulate phase minerals in small letters, in order of volume percent, preceding the capital $\mathrm{C}$ for cumulate, with

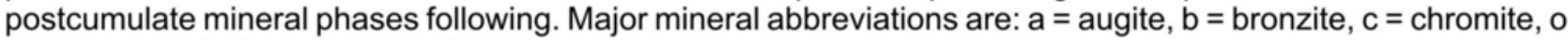
$=$ olivine, $\mathrm{p}=$ plagioclase (see Table 5 for references).

Modified after Schissel et al., 2002. 


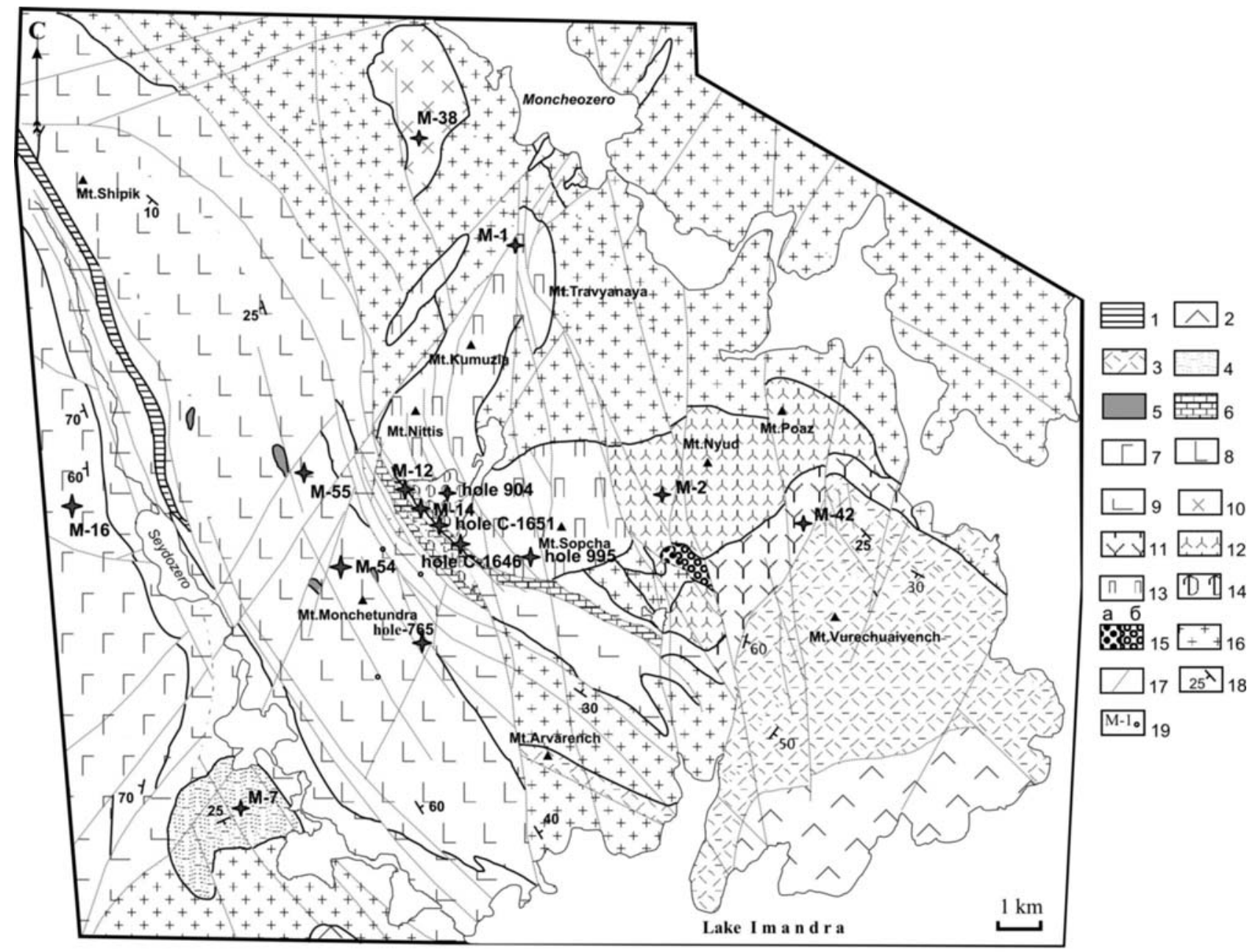

Fig. 4. Geological map of the Monchegorsk layered complex (Smolkin et al., 2004). 


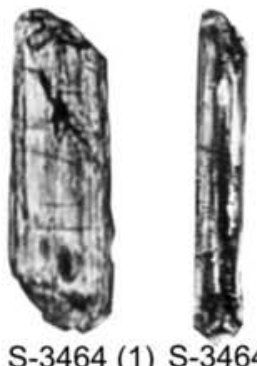

S-3464 (1) S-3464 (4) SA-443 (1) SA-443 magmatic zircon $(50-100 \mu \mathrm{m})$
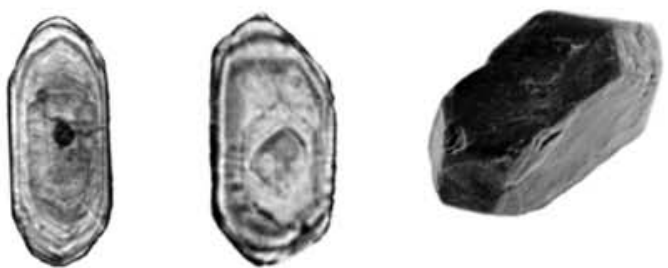

$$
\begin{gathered}
\text { S-3464 (2) S-3464 (3) SA-443 (4) } \\
\text { zircon xenocrystic }(70-80 \mu \mathrm{m})
\end{gathered}
$$

\section{Fedorovo-Pansky Complex}

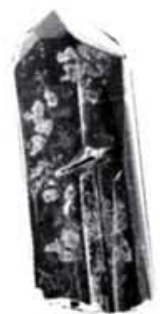

Pan-1 (2)

magmatic zircon (100-120 $\mu \mathrm{m})$

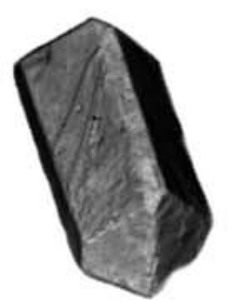

Pan-1 (3)

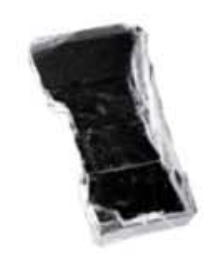

P-6 (4) baddeleyite $(50-70 \mu h$

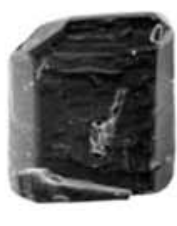

P-6 (5)

Monchepluton and Monchetundra
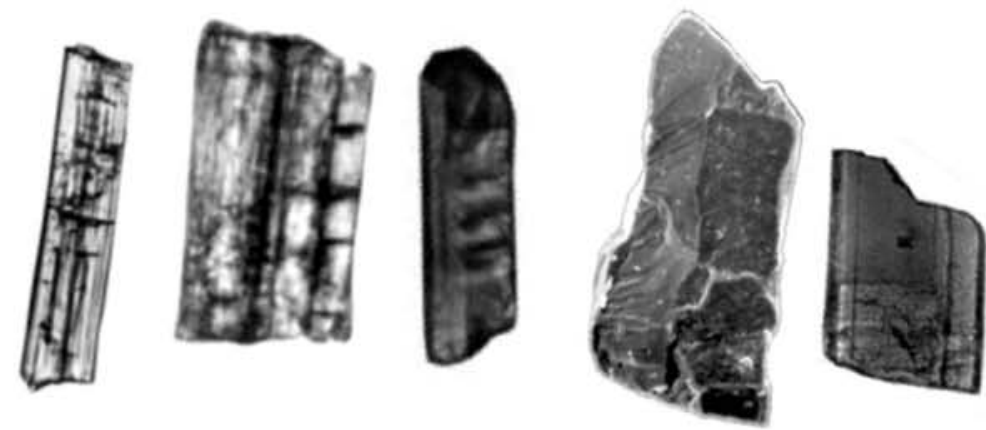

M-2 (3) $\quad \mathrm{M}-1$ (1) $\quad \mathrm{M}-42$ (3) magmatic zircon from Monchepluton

$\mathrm{M}-2$ (1) $\quad \mathrm{M}-42$ (1)

baddeleyite from Monchepluton (80-120 $\mu \mathrm{m})$
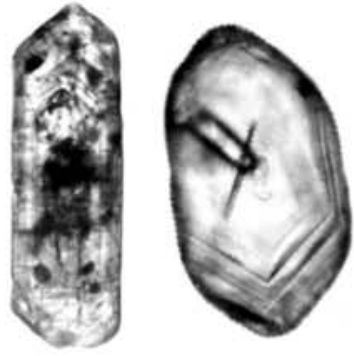

$\mathrm{M}-55$ (1) M-54 (1)

magmatic zircon from Monchetundra $(175 \mu \mathrm{m})$

\section{Imandra lopolith}
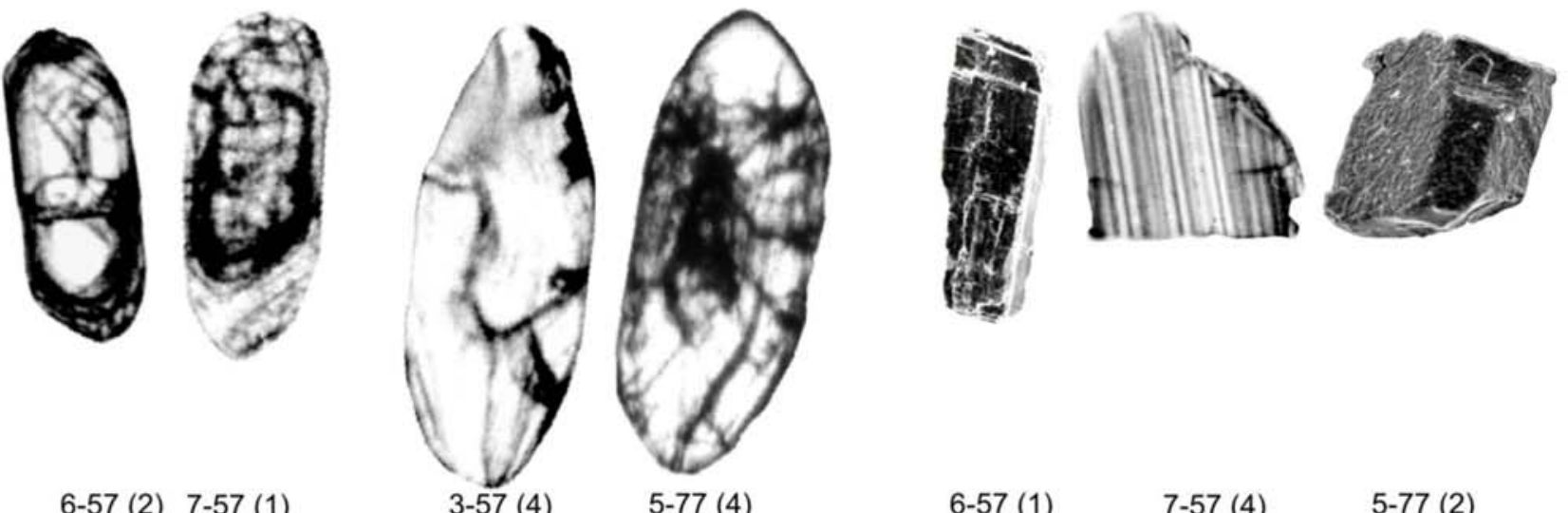

6-57 (2) 7-57 (1)

magmatic zircon $(125 \mathrm{~m})$

zircon xenocrystic $(225 \mathrm{~m})$

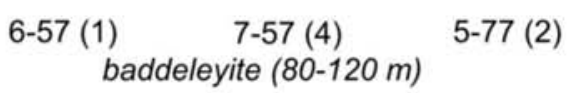

Fig. 5. Photomicrographs of analyzed zircon and baddeleyite. 


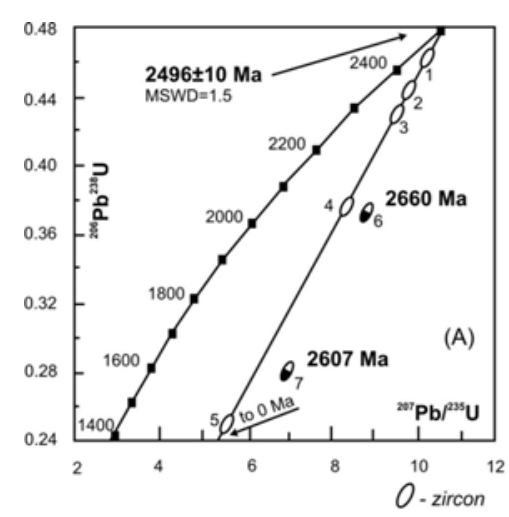

gabbronorite 1-4 (S-3464), 5 (SA-416) and zircon xenocrysts 6-7 (S-3464)

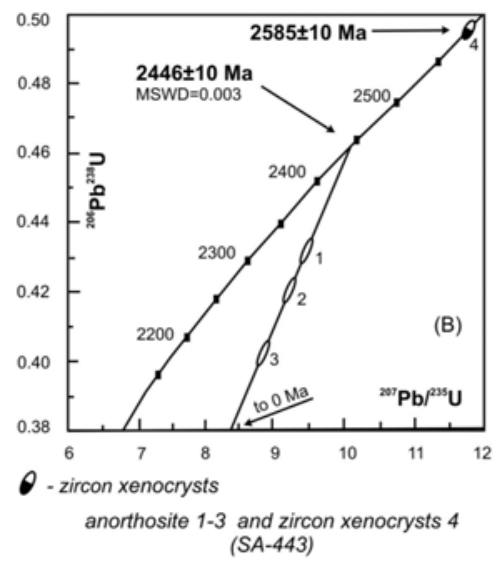

Fig. 6. U-Pb concordia diagrams for zircon from gabbronorite (A) and from anorthosite (B) of the Mt. Generalskaya intrusion (see Table 1).

Legend:

1- large gabbro-dolerite dykes, 2 -metagabbroid rock of the Umbarechka-Imandra complex, 3 - metasedimentary and metavolcanic rocks of the Imandra-Varzuga zone, 4 - lherzolite, websterite, orthopyroxenite and gabbronorite of the Ostrovsky intrusion , 5 - troktolite, 6 - large norite, orthopyroxenite and gabbro dykes, 7 - gabbro-anorthosite of the Chunatundra massif, 8 - metagabbro, gabbronorite and alternating orthopyroxenite and norite of the Monchetundra intrusion, 9 - cataclasis and recrystallization of gabbroid rocks of the Chuna and Monchetundra massifs, and that of Archean amphibolite, gneiss and diorite, $10-$ norite, diorite and granophyric quartz diorite of the Yarva-Varaka massif, 11-14 Monchepluton: 11 - metagabbro, gabbronorite and anorthosite of the Vurechuaivench Foothills, 12 - olivine norite, norite, gabbronorite of the Nyud-Poaz, 13 - peridotite and pyroxenite of the NKT 14 - dunite of the Sopcheozero (Dunite) Block, 15 diorite (a) and metagabbro (б) of the Xth anomaly, 16- Archaean basement rocks; 17 - faults, 18 - dip, 19 - numbered boreholes. 

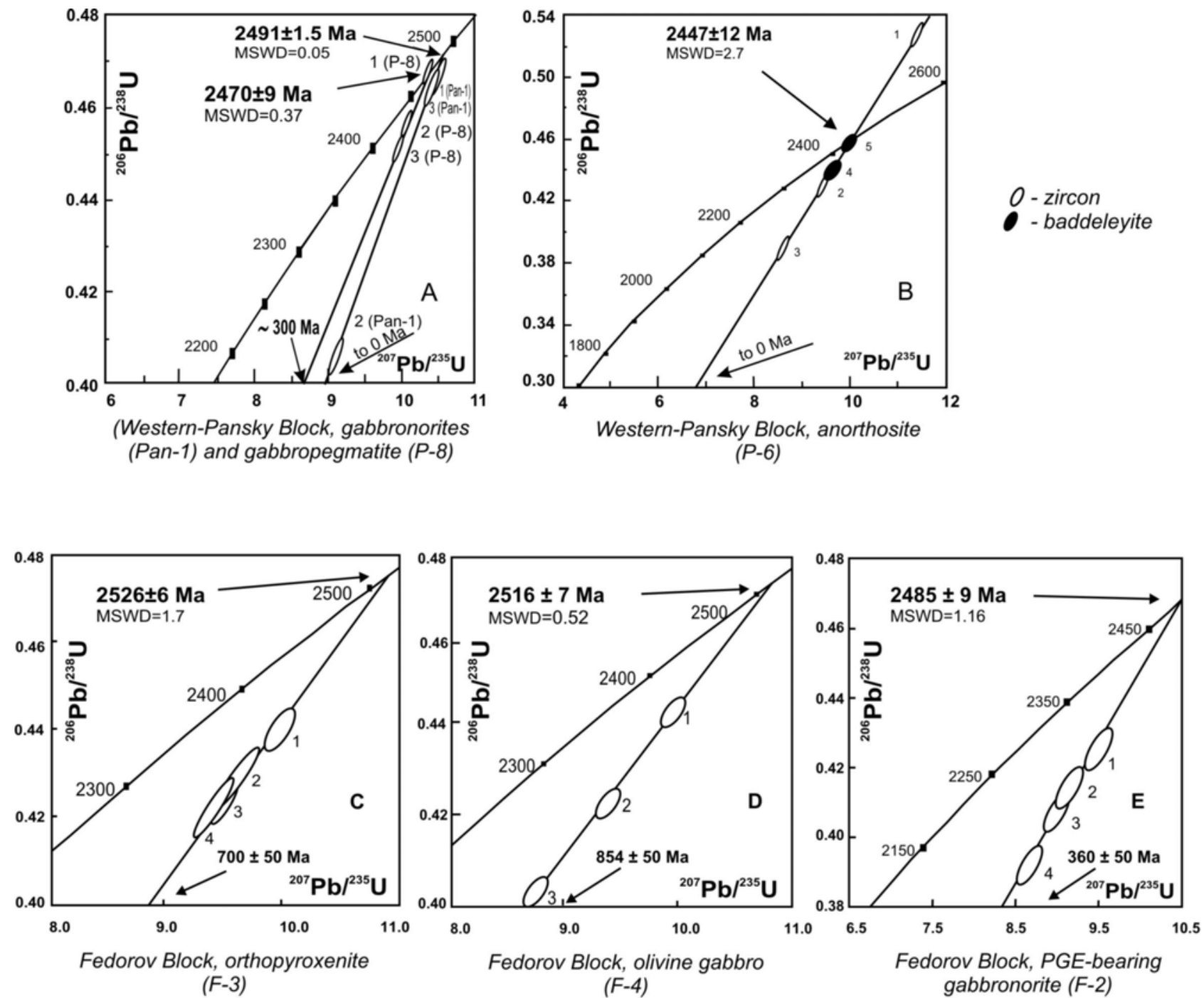

Fig. 7. U-Pb concordia diagrams for the Western-Pansky (A, B) and Fedorov (C, D, E) Blocks of the Fedorovo-Pansky Complex (see Table 2 for U-Pb data and references). 


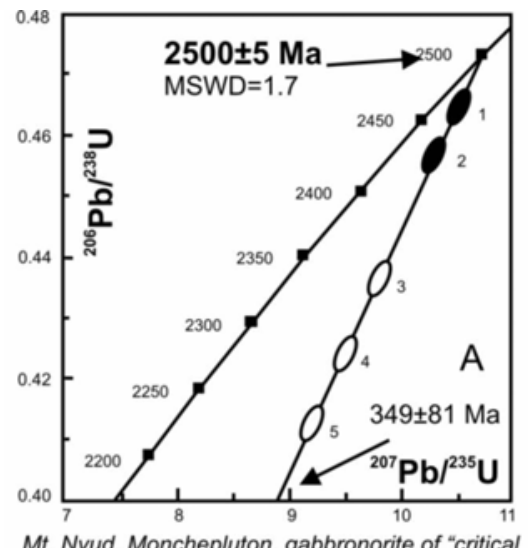

Mt. Nyud, Monchepluton, gabbronorite of "critical horizon" (M-2)

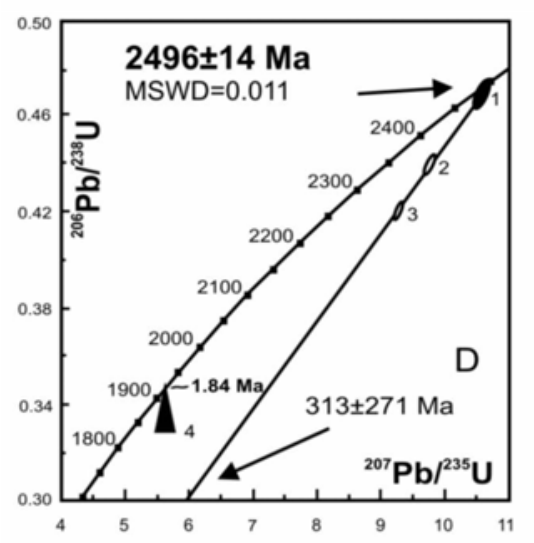

Dunite block, coarse-grained gabbronorite dyke cutting ultramafic rocks, Borehole 1586 (M-14)
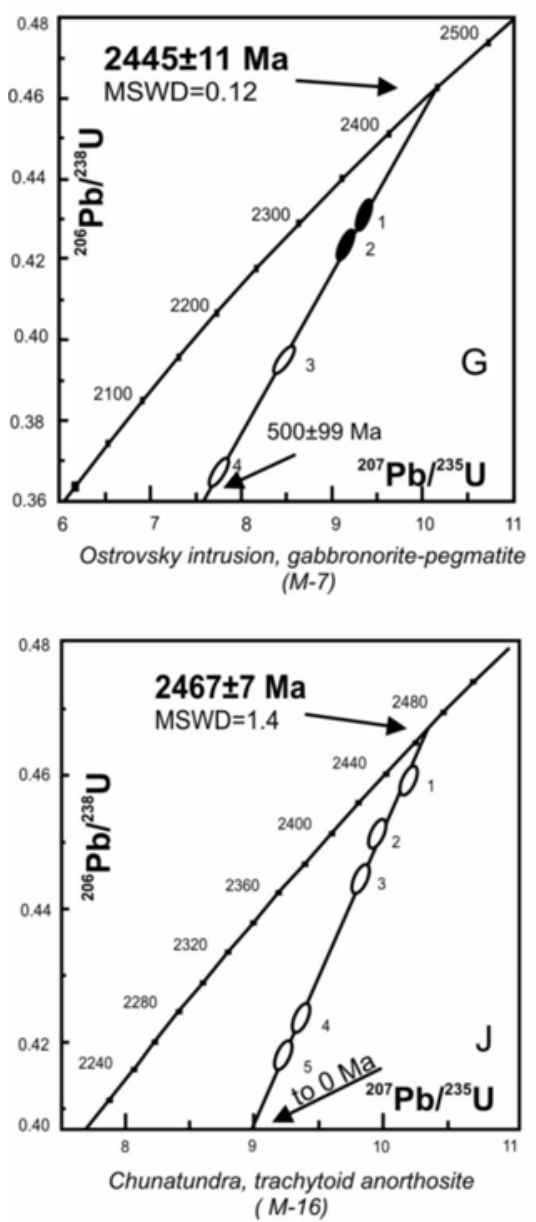
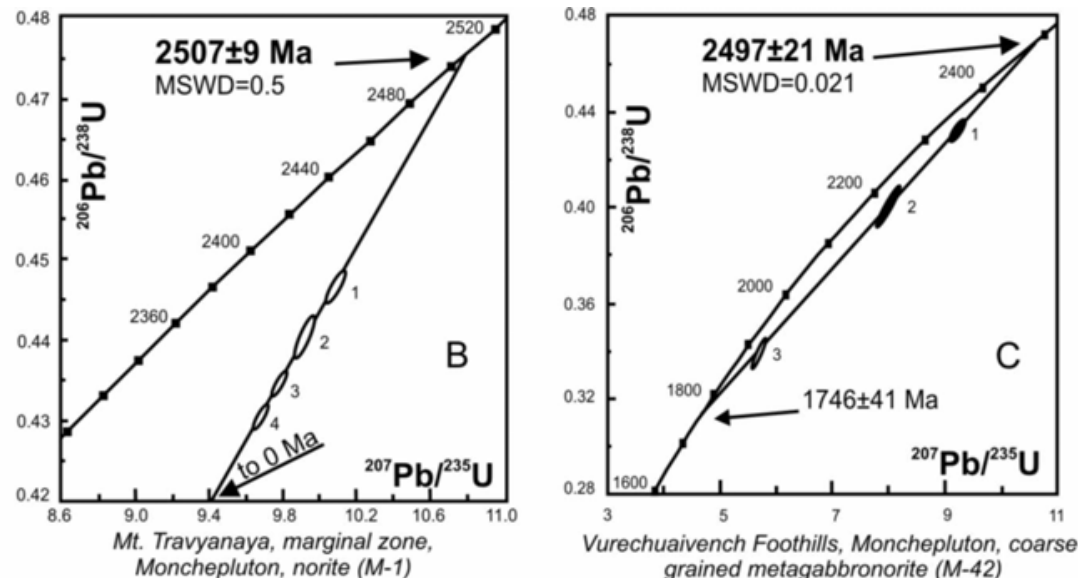

grained metagabbronorite (M-42)
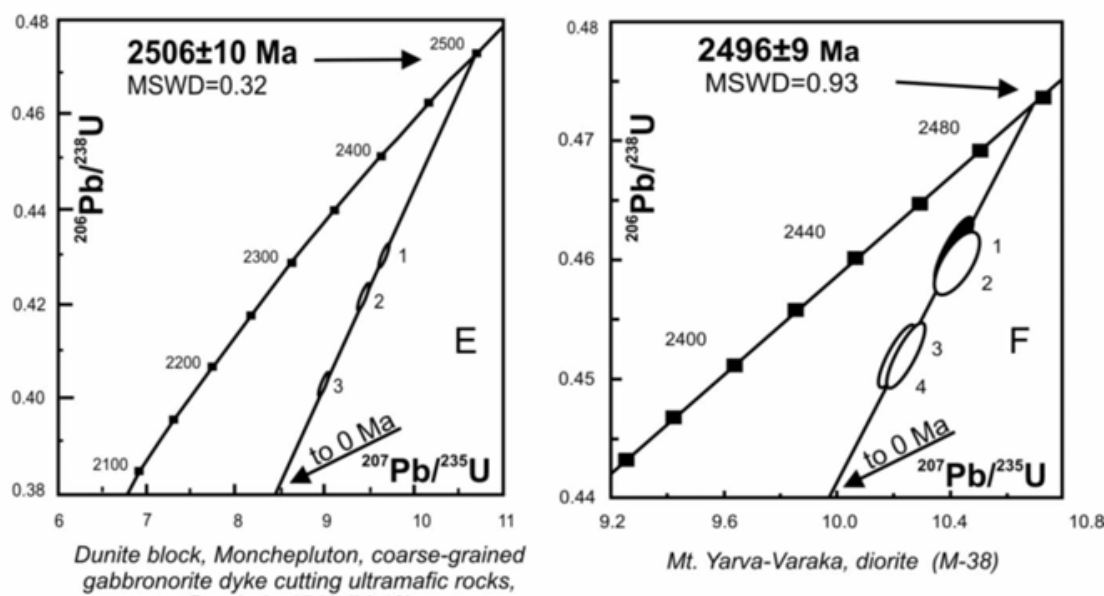
Borehole $1518(M-12)$
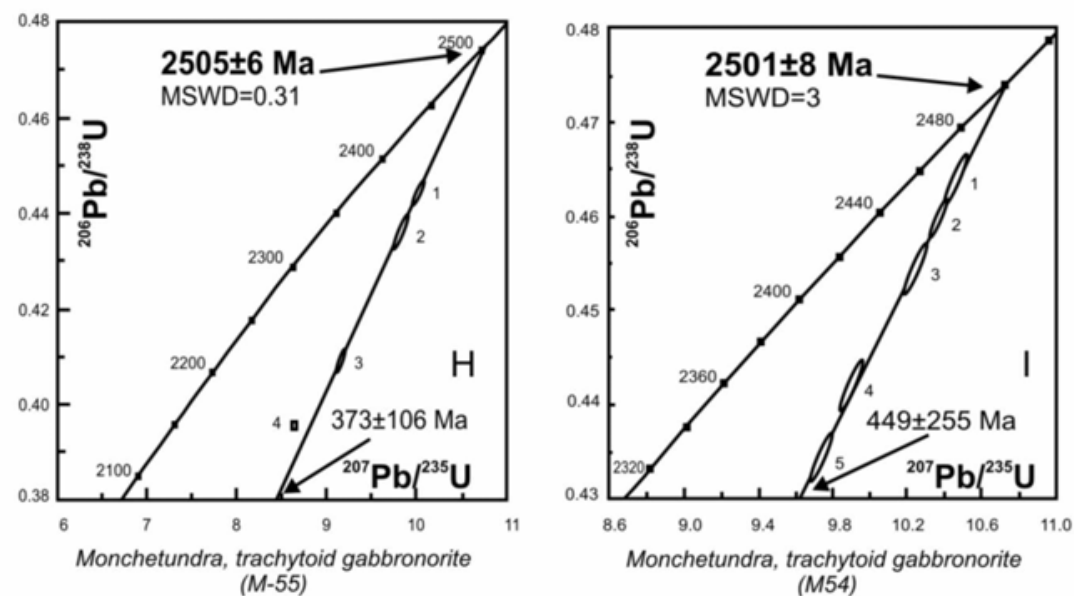

$$
\begin{aligned}
& 0 \text { - zircon } \\
& \text { - baddeleyite } \\
& \Lambda \text { - secondary rutile }
\end{aligned}
$$

Fig. 8. U-Pb concordia diagrams for zircon, baddeleyite and rutile from different rocks of the Monchegorsk Layered Complex (see Table 3). 

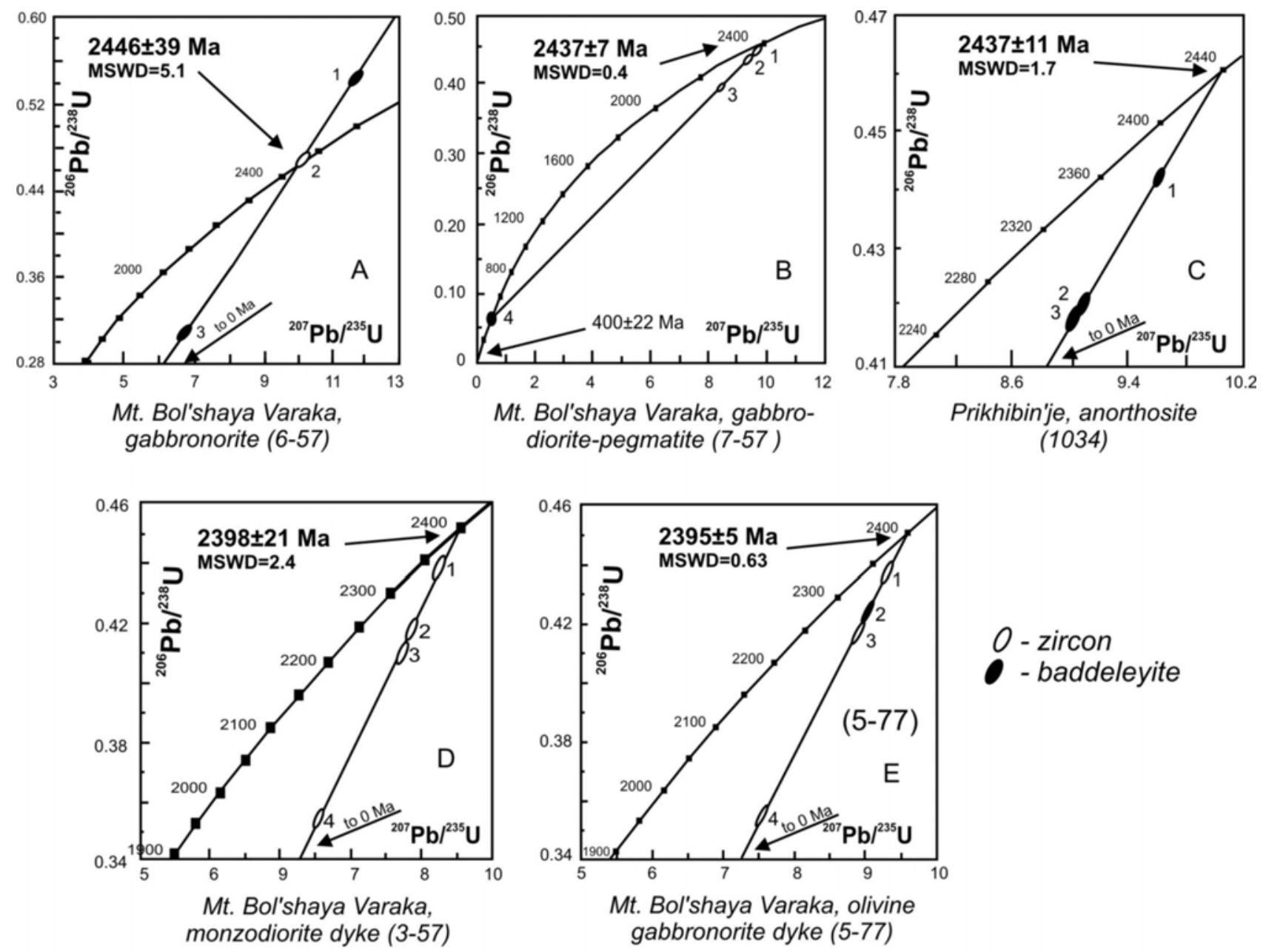

0 - zircon
- baddeleyite

Fig. 9. U-Pb concordia diagrams for zircon and baddeleyite from rocks of the Imandra lopolith (see Table 4). 

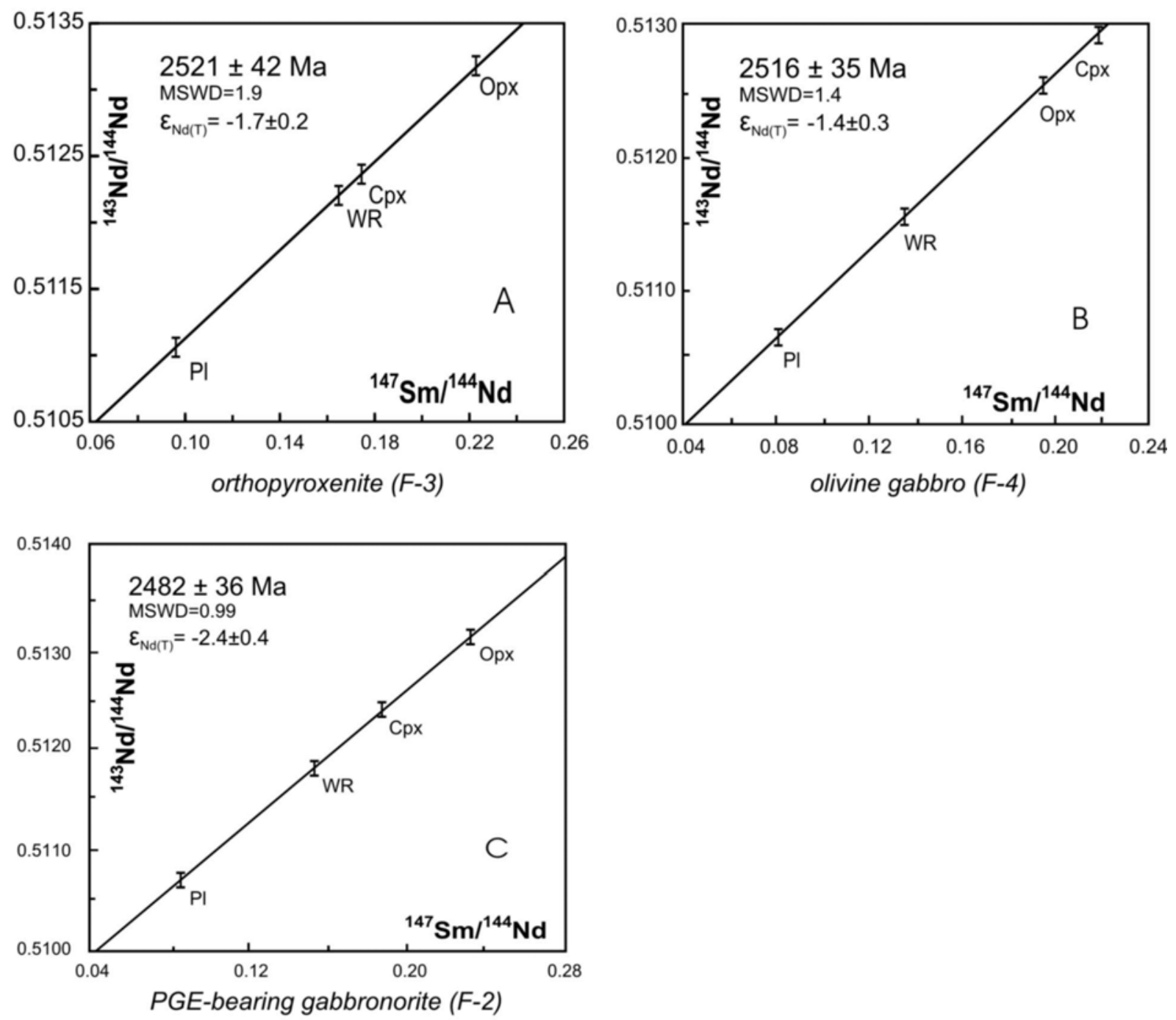

Fig. 10. Mineral Sm-Nd isochrons for rocks and rock-forming minerals of the Fedorov Block of the Fedorovo-Pansky Complex (Serov et al., 2007; see Table 6). 


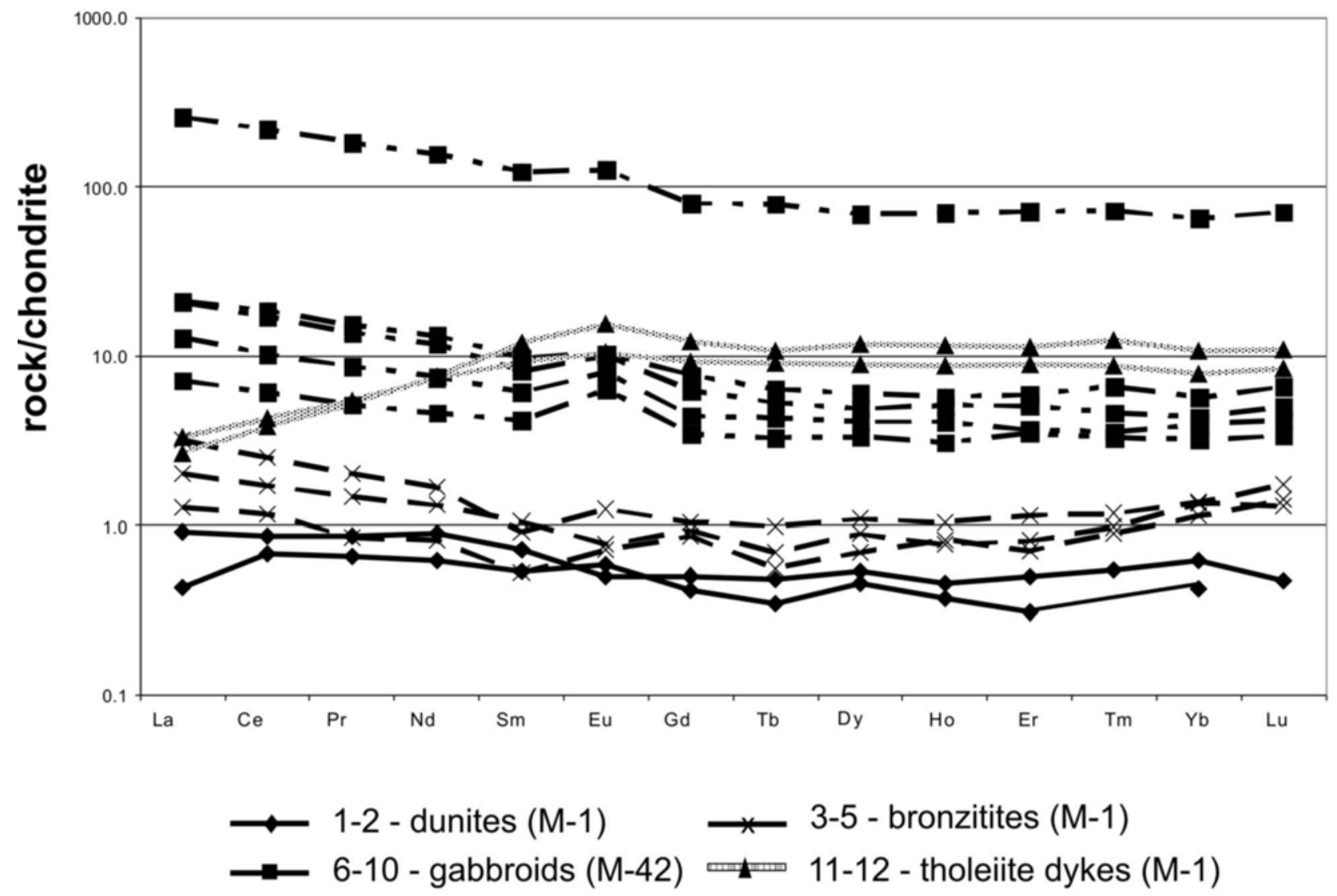

Fig. 11. REE data for rocks of the Monchepluton (plotted according to the data given in Table 7). 


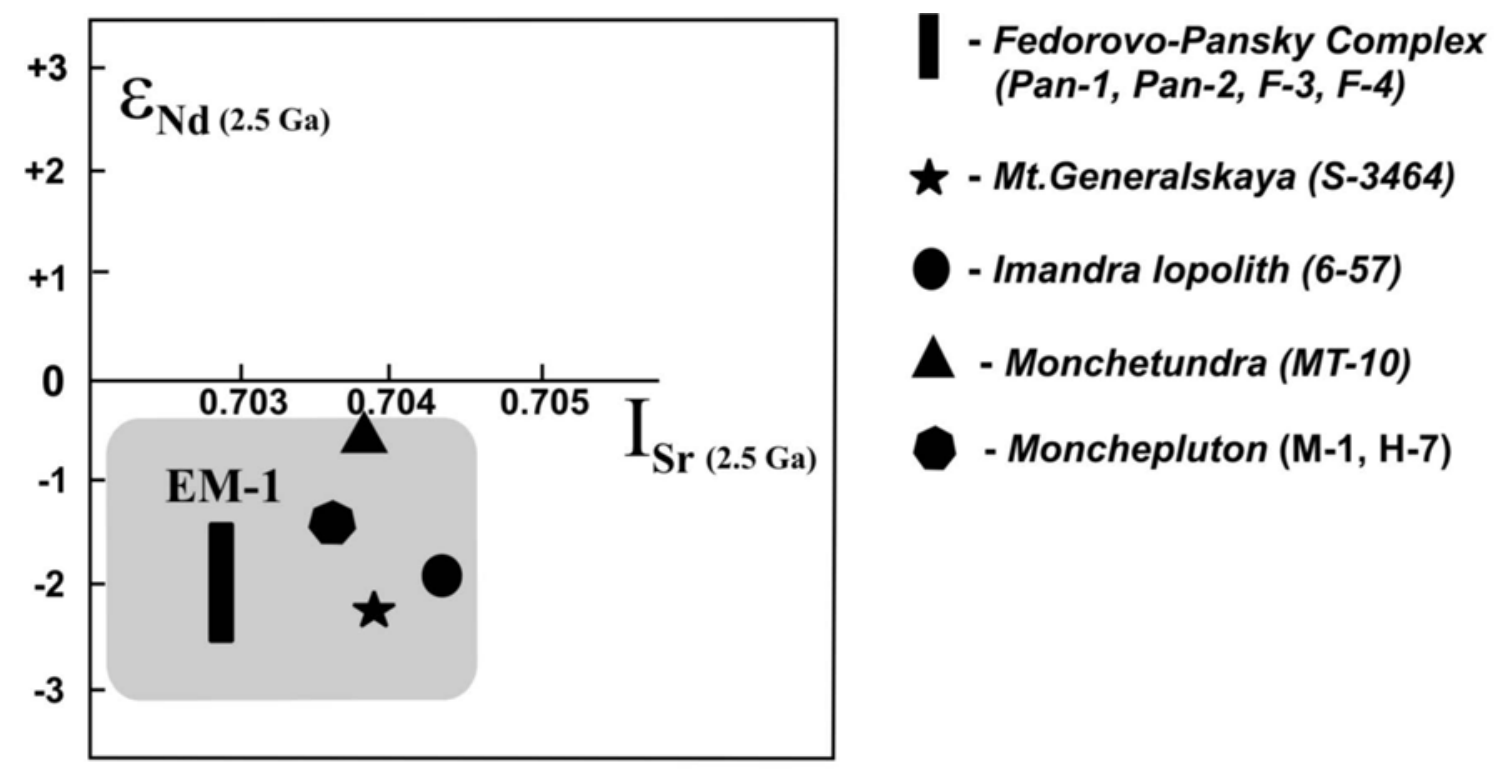

Fig. 12. $\varepsilon_{\mathrm{Nd}}-\mathrm{I}_{\mathrm{Sr}}$ plot of rocks from the Northern (Kola) Belt layered intrusions.

Grey colour in the diagram shows EM-1 reservoir plotted for the layered intrusions of the Kola Peninsula based on the Sm-Nd and Rb-Sr isotope data given in Table 9. 


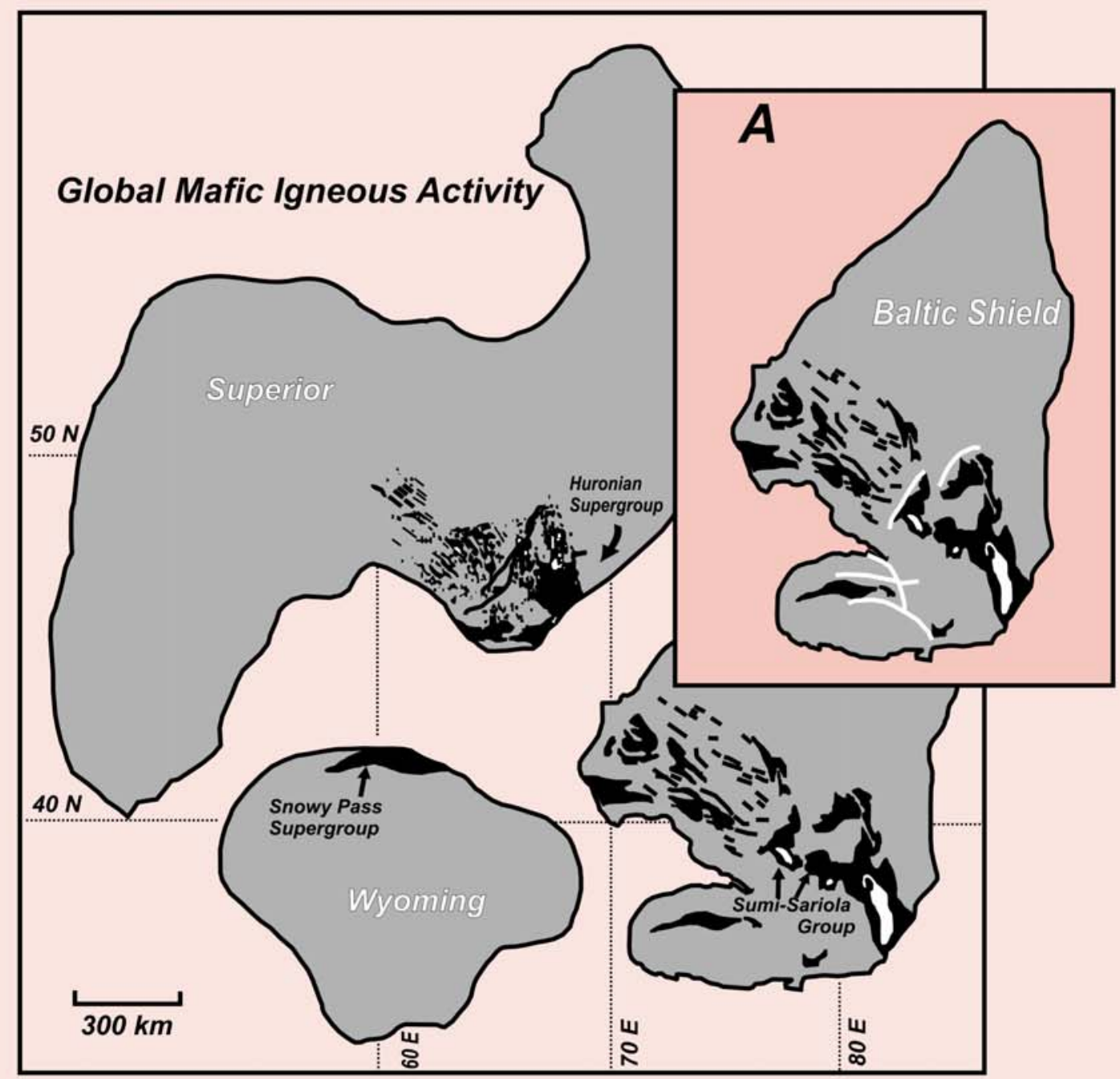

Fig. 13. Continental reconstruction at $2.45 \mathrm{Ga}$ involving the Superior, Wyoming, and Karelian cratons (Heaman, 1997). Patterned regions correspond to $2.45 \mathrm{Ga}$ supracrustal rocks, including flood basalts, such as Huronian Supergroup (Superior), Snowy Pass Supergroup (Wyoming), and Sumi-Sarlola-Strelna Supergroups (Karelia). Orientation of Karelia is based on alignment of Hearst and Karelian dike swarms and interpretation that they represent rift-parallel dykes. Estimated paleolatitudes are determined from paleomagnetic studies; paleolongitudes are arbitrary.

Black colour depicts Paleoproterozoic mafic magmatism (layered intrusions and mafic dykes). A - shows trends ( ) of 2.52-2.44 Ga layered intrusions located on of the N-E Baltic Shield. 
Table 1. U-Pb zircon isotope data for the rocks of the Mt. Generalskaya intrusion (from Bayanova et al., 1999)

\begin{tabular}{|c|c|c|c|c|c|c|c|c|c|}
\hline \multirow{2}{*}{$\underset{\substack{\tilde{Z} \\
\tilde{Z}}}{\stackrel{0}{Z}}$} & \multirow{2}{*}{ 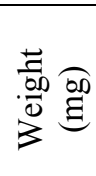 } & \multicolumn{2}{|c|}{$\begin{array}{c}\text { Concentration } \\
(\mathrm{ppm})\end{array}$} & \multicolumn{3}{|c|}{$\mathrm{Pb}$ isotopic composition ${ }^{1}$} & \multicolumn{2}{|c|}{ Isotopic ratios $^{2}$} & \multirow{2}{*}{$\begin{array}{c}\mathrm{Age}^{2} \\
(\mathrm{Ma}) \\
\frac{{ }^{207} \mathrm{~Pb}}{{ }^{206} \mathrm{~Pb}}\end{array}$} \\
\hline & & $\mathrm{Pb}$ & $\mathrm{U}$ & $\frac{{ }^{206} \mathrm{~Pb}}{{ }^{204} \mathrm{~Pb}}$ & $\frac{{ }^{206} \mathrm{~Pb}}{{ }^{207} \mathrm{~Pb}}$ & $\frac{{ }^{206} \mathrm{~Pb}}{{ }^{208} \mathrm{~Pb}}$ & $\frac{{ }^{207} \mathrm{~Pb}}{{ }^{235} \mathrm{U}}$ & $\frac{{ }^{206} \mathrm{~Pb}}{{ }^{238} \mathrm{U}}$ & \\
\hline \multicolumn{10}{|c|}{ (gabbronorite (S-3464) } \\
\hline 1 & 0.7 & 68.0 & 112.1 & 2700 & 5.931 & 2.783 & 10.4131 & 0.45964 & 2501 \\
\hline 2 & 0.9 & 157.1 & 275.5 & 5200 & 6.046 & 2.972 & 9.8889 & 0.43927 & 2490 \\
\hline 3 & 0.8 & 107.5 & 194.5 & 4200 & 6.020 & 2.970 & 9.5879 & 0.42551 & 2491 \\
\hline 4 & 0.8 & 121.3 & 246.3 & 1585 & 5.835 & 2.881 & 8.4272 & 0.37318 & 2495 \\
\hline \multicolumn{10}{|c|}{ (gabbronorite (SA-416) } \\
\hline 5 & 1.3 & 76.4 & 227.5 & 2880 & 6.010 & 2.512 & 5.5480 & 0.24787 & 2480 \\
\hline \multicolumn{10}{|c|}{ (zircon xenocrysts (S-3464) } \\
\hline 6 & 0.9 & 133.9 & 296.1 & 1000 & 5.311 & 5.050 & 8.9624 & 0.37118 & 2607 \\
\hline 7 & 0.6 & 113.9 & 343.5 & 1400 & 5.281 & 5.621 & 6.9341 & 0.27819 & 2660 \\
\hline \multicolumn{10}{|c|}{ (anorthosite (SA-443) } \\
\hline 1 & 0.8 & 109.4 & 199.8 & 4600 & 6.170 & 3.212 & 9.4737 & 0.43046 & 2452 \\
\hline 2 & 0.8 & 115.9 & 208.6 & 1100 & 5.851 & 2.870 & 9.2448 & 0.41956 & 2454 \\
\hline 3 & 0.5 & 52.6 & 101.9 & 1750 & 5.991 & 3.131 & 8.8624 & 0.40153 & 2456 \\
\hline \multicolumn{10}{|c|}{ (zircon xenocrysts (SA-443) } \\
\hline 4 & 0.5 & 369.9 & 400.1 & 2600 & 5.641 & 1.023 & 11.7529 & 0.49322 & 2585 \\
\hline
\end{tabular}

${ }^{1}$ All ratios are corrected for blanks of $0.1 \mathrm{ng}$ for $\mathrm{Pb}$ and $0.04 \mathrm{ng}$ for $\mathrm{U}$ and for mass discrimination of $0.17 \pm 0.05 \%$ ${ }^{2}$ Correction for common $\mathrm{Pb}$ was determined for the age according to Stacey and Kramers (1975). 
Table 2. U-Pb baddeleyite ( $b d$ ) and zircon isotope data from the Western-Pansky and Fedorov Blocks of the Fedorovo-Pansky Complex

\begin{tabular}{|c|c|c|c|c|c|c|c|c|c|}
\hline \multirow[t]{2}{*}{$\begin{array}{l}\text { Sample } \\
\text { No }\end{array}$} & \multirow[t]{2}{*}{$\begin{array}{l}\text { Weight } \\
\text { (mg) }\end{array}$} & \multicolumn{2}{|c|}{$\begin{array}{l}\text { Concentration } \\
(\mathrm{ppm})\end{array}$} & \multicolumn{3}{|c|}{$\mathrm{Pb}$ isotopic composition ${ }^{1}$} & \multicolumn{2}{|c|}{ Isotopic ratios $^{2}$} & \multirow{2}{*}{$\begin{array}{l}\mathrm{Age}^{2} \\
\text { (Ma) } \\
\frac{{ }^{207} \mathrm{~Pb}}{{ }^{206} \mathrm{~Pb}}\end{array}$} \\
\hline & & $\mathrm{Pb}$ & $\mathrm{U}$ & $\frac{{ }^{206} \mathrm{~Pb}}{{ }^{204} \mathrm{~Pb}}$ & $\frac{{ }^{206} \mathrm{~Pb}}{{ }^{207} \mathrm{~Pb}}$ & $\frac{{ }^{206} \mathrm{~Pb}}{{ }^{208} \mathrm{~Pb}}$ & $\frac{{ }^{207} \mathrm{~Pb}}{{ }^{235} \mathrm{U}}$ & $\frac{{ }^{206} \mathrm{~Pb}}{{ }^{238} \mathrm{U}}$ & \\
\hline \multicolumn{10}{|c|}{ (Western-Pansky Block, gabbronorites (Pan-1); from Bayanova, 2004) } \\
\hline 1 & 3.30 & 95.0 & 144 & 11740 & 6.091 & 3.551 & 10.510 & 0.4666 & 2491 \\
\hline 2 & 1.90 & 70.0 & 142 & 10300 & 6.100 & 4.220 & 9.135 & 0.4061 & 2489 \\
\hline 3 & 1.60 & 84.0 & 144 & 6720 & 6.062 & 3.552 & 10.473 & 0.4650 & 2491 \\
\hline \multicolumn{10}{|c|}{ (Western-Pansky Block, gabbropegmatite (P-8); from Balashov et al., 1993) } \\
\hline 1 & 5.90 & 95.0 & 158 & 3240 & 5.991 & 3.081 & 10.435 & 0.4681 & 2471 \\
\hline 2 & 7.30 & 181.0 & 287 & 8870 & 6.161 & 2.260 & 10.092 & 0.4554 & 2465 \\
\hline 3 & 1.25 & 125.0 & 200 & 3400 & 6.012 & 2.312 & 10.082 & 0.4532 & 2468 \\
\hline \multicolumn{10}{|c|}{ (Western-Pansky Block, anorthosite (P-6); from Bayanova, 2004) } \\
\hline 1 & 0.75 & 218.0 & 322 & 5740 & 6.230 & 3.263 & 11.682 & 0.5352 & 2438 \\
\hline 2 & 0.10 & 743.0 & 1331 & 3960 & 6.191 & 3.151 & 9.588 & 0.4393 & 2438 \\
\hline 3 & 0.20 & 286.0 & 577 & 2980 & 6.021 & 3.192 & 8.643 & 0.3874 & 2474 \\
\hline $4(b d)$ & 1.00 & 176.0 & 396 & 14780 & 6.290 & 63.610 & 9.548 & 0.4380 & 2435 \\
\hline $5(b d)$ & 0.26 & 259.0 & 560 & 3360 & 6.132 & 54.950 & 9.956 & 0.4533 & 2443 \\
\hline \multicolumn{10}{|c|}{ (Fedorov Block, orthopyroxenite (F-3); from Nitkina, 2006) } \\
\hline 1 & 0.75 & 48.0 & 60.9 & 825 & 4.9191 & 1.3039 & 10.0461 & 0.44249 & 2504 \\
\hline 2 & 0.80 & 374.0 & 598.6 & 4588 & 6.0459 & 1.9650 & 9.6782 & 0.43153 & 2484 \\
\hline 3 & 0.85 & 410.2 & 630.2 & 4521 & 6.0281 & 1.6592 & 9.5667 & 0.42539 & 2488 \\
\hline 4 & 1.00 & 271.0 & 373.1 & 2552 & 5.9916 & 1.2393 & 9.4700 & 0.42406 & 2476 \\
\hline \multicolumn{10}{|c|}{ (Fedorov Block, olivine gabbro (F-4); from Nitkina, 2006) } \\
\hline 1 & 1.80 & 725.3 & 1322.8 & 14649 & 6.1121 & 3.8177 & 10.0132 & 0.44622 & 2484 \\
\hline 2 & 2.00 & 731.3 & 1382.8 & 8781 & 6.1522 & 3.5517 & 9.4306 & 0.42454 & 2467 \\
\hline 3 & 1.95 & 680.9 & 1374.0 & 7155 & 6.2645 & 3.6939 & 8.7401 & 0.40155 & 2433 \\
\hline \multicolumn{10}{|c|}{ (Fedorov block, PGE-bearing gabbronorite (F-2); from Nitkina, 2006) } \\
\hline 1 & 0.30 & 498.0 & 833.4 & 2081 & 5.9502 & 2.2111 & 9.49201 & 0.42493 & 2477 \\
\hline 2 & 0.65 & 513.8 & 932.2 & 5274 & 6.1519 & 2.6371 & 9.1373 & 0.41378 & 2458 \\
\hline 3 & 0.55 & 583.2 & 999.3 & 3194 & 6.1132 & 2.0528 & 8.9869 & 0.40832 & 2452 \\
\hline 4 & 0.80 & 622.5 & 1134.5 & 4114 & 6.1161 & 2.1914 & 8.6638 & 0.39165 & 2460 \\
\hline
\end{tabular}


${ }^{1}$ All ratios are corrected for blanks of $0.1 \mathrm{ng}$ for $\mathrm{Pb}$ and $0.04 \mathrm{ng}$ for $\mathrm{U}$ and for mass discrimination of $0.17 \pm 0.05 \%$.

${ }^{2}$ Correction for common $\mathrm{Pb}$ was determined for the age according to Stacey and Kramers (1975).

Table 3. U-Pb baddeleyite ( $b d$ ), zircon and rutile (ru) isotope data from the Monchegorsk Layered Complex

\begin{tabular}{|c|c|c|c|c|c|c|c|c|c|}
\hline \multirow{2}{*}{ 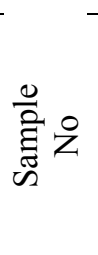 } & \multirow{2}{*}{ 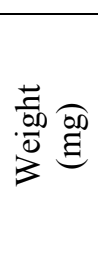 } & \multicolumn{2}{|c|}{$\begin{array}{l}\text { Concentration } \\
(\mathrm{ppm})\end{array}$} & \multicolumn{3}{|c|}{$\mathrm{Pb}$ isotopic composition ${ }^{1}$} & \multicolumn{2}{|c|}{ Isotopic ratios $^{2}$} & \multirow{2}{*}{$\begin{array}{l}\mathrm{Age}^{2} \\
(\mathrm{Ma}) \\
\\
\frac{{ }^{207} \mathrm{~Pb}}{{ }^{206} \mathrm{~Pb}}\end{array}$} \\
\hline & & $\mathrm{Pb}$ & U & $\frac{{ }^{206} \mathrm{~Pb}}{{ }^{204} \mathrm{~Pb}}$ & $\frac{{ }^{206} \mathrm{~Pb}}{{ }^{207} \mathrm{~Pb}}$ & $\frac{{ }^{206} \mathrm{~Pb}}{{ }^{208} \mathrm{~Pb}}$ & $\frac{{ }^{207} \mathrm{~Pb}}{{ }^{235} \mathrm{U}}$ & $\frac{{ }^{206} \mathrm{~Pb}}{{ }^{238} \mathrm{U}}$ & \\
\hline \multicolumn{10}{|c|}{ (“critical horizon", Mt. Nyud Monchepluton, gabbronorite (M-2); from Bayanova, 2004) } \\
\hline $1(b d)$ & 0.70 & 93.1 & 198.8 & 9432 & 6.0586 & 103.8300 & 10.4643 & 0.4636 & 2495 \\
\hline $2(b d)$ & 0.40 & 170.8 & 364.4 & 3589 & 5.9833 & 50.7070 & 10.3199 & 0.4574 & 2494 \\
\hline 3 & 0.40 & 117.4 & 183.1 & 4590 & 6.0153 & 1.8703 & 9.8274 & 0.4359 & 2492 \\
\hline 4 & 0.80 & 187.9 & 308.4 & 13664 & 6.1169 & 1.9750 & 9.4740 & 0.4227 & 2483 \\
\hline 5 & 0.50 & 152.2 & 252.5 & 5300 & 6.0842 & 1.8994 & 9.2129 & 0.4125 & 2477 \\
\hline \multicolumn{10}{|c|}{ (marginal zone, Mt. Travyanaya Monchepluton, norite (M-1); from Smolkin et al., 2004) } \\
\hline 1 & 0.30 & 308.3 & 504.8 & 5778 & 6.0202 & 2.3805 & 10.0760 & 0.4458 & 2497 \\
\hline 2 & 0.35 & 185.4 & 319.8 & 8358 & 6.0582 & 2.7721 & 9.9277 & 0.4402 & 2493 \\
\hline 3 & 0.40 & 264.5 & 441.6 & 23762 & 6.1006 & 2.2929 & 9.7814 & 0.4342 & 2491 \\
\hline 4 & 0.40 & 434.8 & 793.1 & 6273 & 6.0541 & 3.2613 & 9.7060 & 0.4314 & 2489 \\
\hline
\end{tabular}


(Vurechuaivench Foothills Monchepluton, coarse-grained metagabbronorite (M-42); present study)

\begin{tabular}{|c|c|c|c|c|c|c|c|c|c|}
\hline $1(b d)$ & 0.80 & 150.1 & 271.4 & 2982 & 6.3099 & 3.2054 & 9.23762 & 0.43446 & 2393 \\
\hline $2(b d)$ & 0.65 & 65.1 & 122.6 & 2080 & 6.5863 & 2.7920 & 8.13574 & 0.40516 & 2295 \\
\hline 3 & 0.75 & 137.4 & 288.5 & 911 & 6.4805 & 2.3018 & 5.75090 & 0.34208 & 2228 \\
\hline \multicolumn{10}{|c|}{ (Dunite block, Monchepluton, coarse-grained gabbronorite dyke cutting ultramafic rocks, hole 1586 (M-14); from Bayanova, 2004) } \\
\hline $1(b d)$ & 0.50 & 5.3 & 10.3 & 1307 & 5.7748 & 12.4320 & 10.5720 & 0.4684 & 2494 \\
\hline 2 & 0.80 & 358.7 & 309.2 & 13360 & 6.1029 & 0.5312 & 9.8622 & 0.4391 & 2486 \\
\hline 3 & 0.60 & 321.8 & 362.1 & 3791 & 6.0407 & 0.7838 & 9.3919 & 0.4199 & 2479 \\
\hline $4(r u)^{3}$ & 1.30 & 7.5 & 4.5 & 28 & 1.7085 & 0.8077 & 5.7139 & 0.3328 & 2022 \\
\hline \multicolumn{10}{|c|}{ Dunite block, Monchepluton, coarse-grained gabbronorite dyke cutting ultramafic rocks, hole 518 (M-12); from Smolkin et al., 2004) } \\
\hline 1 & 0.45 & 221.4 & 409.6 & 2152 & 5.9237 & 3.5776 & 9.6682 & 0.4303 & 2487 \\
\hline 2 & 0.30 & 321.7 & 542.6 & 11260 & 6.1264 & 2.2049 & 9.4976 & 0.4249 & 2478 \\
\hline 3 & 0.50 & 164.9 & 302.4 & 1952 & 5.9508 & 2.5602 & 8.9806 & 0.4031 & 2472 \\
\hline \multicolumn{10}{|c|}{ (Mt. Yarva-Varaka, diorite (M-38); from Bayanova, 2004) } \\
\hline $1(b d)$ & 0.50 & 32.9 & 70.0 & 5615 & 6.0158 & 53.309 & 10.419 & 0.4608 & 2497 \\
\hline 2 & 0.80 & 310.5 & 515.4 & 2587 & 5.9089 & 2.9118 & 10.420 & 0.4597 & 2501 \\
\hline 3 & 1.40 & 151.8 & 262.7 & 4840 & 5.9895 & 3.1873 & 10.242 & 0.4519 & 2501 \\
\hline 4 & 0.70 & 273.2 & 472.5 & 4590 & 5.9970 & 3.1828 & 10.217 & 0.4518 & 2497 \\
\hline \multicolumn{10}{|c|}{ (Ostrovsky intrusion, gabbronorite-pegmatite (M-7); from Bayanova, 2004) } \\
\hline $1(b d)$ & 0.45 & 28.6 & 63.9 & 1820 & 6.162 & 29.610 & 9.350 & 0.4311 & 2405 \\
\hline $2(b d)$ & 0.55 & 36.3 & 83.7 & 3380 & 6.346 & 42.038 & 9.210 & 0.4248 & 2389 \\
\hline 3 & 0.45 & 336.4 & 694.8 & 9420 & 6.378 & 3.797 & 8.471 & 0.3953 & 2407 \\
\hline 4 & 0.35 & 89.1 & 187.6 & 3700 & 6.375 & 2.942 & 7.756 & 0.3667 & 2384 \\
\hline \multicolumn{10}{|c|}{ (Monchetundra, trachytoid gabbronorite (M-55); from Smolkin et al., 2004) } \\
\hline 1 & 0.50 & 110.9 & 172.9 & 8690 & 6.0591 & 1.9737 & 10.0171 & 0.444092 & 2493 \\
\hline 2 & 0.35 & 37.7 & 61.0 & 1122 & 5.7260 & 2.2170 & 9.82794 & 0.436123 & 2492 \\
\hline 3 & 0.25 & 168.3 & 277.7 & 6350 & 6.0914 & 1.8221 & 9.15540 & 0.409417 & 2479 \\
\hline 4 & 0.30 & 122.6 & 213.5 & 6159 & 6.2294 & 1.9243 & 8.64155 & 0.395489 & 2439 \\
\hline \multicolumn{10}{|c|}{ (Monchetundra, trachytoid gabbronorite (M-54); from Smolkin et al., 2004) } \\
\hline 1 & 0.50 & 308.9 & 494.5 & 9172 & 6.0283 & 2.4881 & 10.47020 & 0.46359 & 2503 \\
\hline 2 & 0.35 & 374.3 & 587.5 & 18868 & 6.0791 & 2.2742 & 10.40220 & 0.46050 & 2496 \\
\hline 3 & 0.40 & 72.8 & 118.6 & 6833 & 6.0271 & 2.5023 & 10.25210 & 0.45405 & 2498 \\
\hline 4 & 0.25 & 206.3 & 333.1 & 7831 & 6.0324 & 2.1148 & 9.90668 & 0.44177 & 2499 \\
\hline 5 & 0.45 & 196.6 & 311.9 & 14844 & 6.1123 & 1.9269 & 9.74196 & 0.43412 & 2484 \\
\hline \multicolumn{10}{|c|}{ Chunatundra, trachytoid anorthosite (M-16); from Bayanova, 2004) } \\
\hline 1 & 0.20 & 80.3 & 138.4 & 2710 & 6.020 & 3.404 & 10.216 & 0.4589 & 2471 \\
\hline 2 & 2.05 & 122.83 & 214.1 & 4420 & 6.144 & 3.293 & 9.999 & 0.4527 & 2455 \\
\hline 3 & 0.30 & 141.3 & 251.0 & 5140 & 6.137 & 3.291 & 9.831 & 0.4443 & 2461 \\
\hline 4 & 0.60 & 92.7 & 169.4 & 7860 & 6.148 & 2.970 & 9.388 & 0.4228 & 2467 \\
\hline 5 & 0.20 & 46.5 & 86.1 & 1090 & 5.805 & 3.242 & 9.262 & 0.4180 & 2463 \\
\hline
\end{tabular}

${ }^{1}$ All ratios are corrected for blanks of $0.08 \mathrm{ng}$ for $\mathrm{Pb}$ и $0.04 \mathrm{ng}$ for $\mathrm{U}$ and for mass discrimination of $0.12 \pm 0.04 \%$.

${ }^{2}$ Correction for common $\mathrm{Pb}$ was determined for the age according to Stacey and Kramers (1975).

${ }^{3}$ Corrected for isotope composition of light cogenetic plagioclase: ${ }^{206} \mathrm{~Pb} /{ }^{204} \mathrm{~Pb}=14.041 \pm 0.005,{ }^{207} \mathrm{~Pb} /{ }^{204} \mathrm{~Pb}$ $=14.581 \pm 0.007,{ }^{208} \mathrm{~Pb} /{ }^{204} \mathrm{~Pb}=35.58 \pm 0.02$.

Table 4. U-Pb baddeleyite ( $b d$ ) and zircon isotope data from the rocks of the Imandra lopolith (from Bayanova, 2004) 


\begin{tabular}{|c|c|c|c|c|c|c|c|c|c|}
\hline \multirow{2}{*}{ 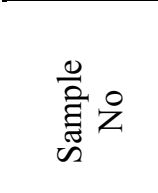 } & \multirow{2}{*}{ 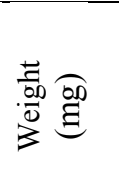 } & \multicolumn{2}{|c|}{$\begin{array}{l}\text { Concentration } \\
(\mathrm{ppm})\end{array}$} & \multicolumn{3}{|c|}{$\mathrm{Pb}$ isotopic composition ${ }^{1}$} & \multicolumn{2}{|c|}{ Isotopic ratios $^{2}$} & \multirow{2}{*}{$\begin{array}{c}\begin{array}{c}\text { Age } \\
(\mathrm{Ma})\end{array} \\
\frac{{ }^{207} \mathrm{~Pb}}{{ }^{206} \mathrm{~Pb}}\end{array}$} \\
\hline & & $\mathrm{Pb}$ & $\mathrm{U}$ & $\frac{{ }^{206} \mathrm{~Pb}}{{ }^{204} \mathrm{~Pb}}$ & $\frac{{ }^{206} \mathrm{~Pb}}{{ }^{207} \mathrm{~Pb}}$ & $\frac{{ }^{206} \mathrm{~Pb}}{{ }^{208} \mathrm{~Pb}}$ & $\frac{{ }^{207} \mathrm{~Pb}}{{ }^{235} \mathrm{U}}$ & $\frac{{ }^{206} \mathrm{~Pb}}{{ }^{238} \mathrm{U}}$ & \\
\hline \multicolumn{10}{|c|}{ (Mt. Bol'shaya Varaka, gabbronorite (6-57) } \\
\hline $1(b d)$ & 0.60 & 257 & 463 & 5500 & 6.141 & 46.2300 & 12.0200 & 0.5435 & 2461 \\
\hline 2 & 1.10 & 123 & 183 & 8040 & 6.231 & 2.0930 & 10.3600 & 0.4730 & 2445 \\
\hline $3(b d)$ & 0.70 & 170 & 534 & 2570 & 6.162 & 31.0400 & 6.7081 & 0.3088 & 2430 \\
\hline \multicolumn{10}{|c|}{ (Mt. Bol'shaya Varaka, gabbro-diorite-pegmatite (7-57) } \\
\hline 1 & 0.90 & 274 & 474 & 8100 & 6.248 & 3.1196 & 9.9036 & 0.4532 & 2440 \\
\hline 2 & 0.50 & 71 & 129 & 2310 & 6.108 & 3.4370 & 9.5718 & 0.4387 & 2437 \\
\hline 3 & 0.60 & 125 & 232 & 2770 & 6.132 & 3.4848 & 9.4215 & 0.4311 & 2440 \\
\hline $4(b d)$ & 0.30 & 60 & 128 & 1220 & 6.034 & 24.2930 & 9.4746 & 0.4425 & 2405 \\
\hline \multicolumn{10}{|c|}{ (Prikhibin'je, anorthosite (1034) } \\
\hline $1(b d)$ & 0.90 & 457.9 & 1032.6 & 28560 & 6.334 & 117.5 & 9.6090 & 0.4419 & 2431 \\
\hline $2(b d)$ & 1.00 & 174.6 & 410.7 & 6280 & 6.316 & 87.0 & 9.1080 & 0.4219 & 2419 \\
\hline $3(b d)$ & 0.80 & 330.6 & 790.5 & 14210 & 6.351 & 93.5 & 9.0000 & 0.4162 & 2422 \\
\hline \multicolumn{10}{|c|}{ (Mt. Bol'shaya Varaka, monzodiorite dyke (3-57) } \\
\hline 1 & 0.50 & 119 & 102 & 17330 & 5.821 & 0.5701 & 9.6611 & 0.4530 & 2397 \\
\hline 2 & 0.71 & 114 & 104 & 1910 & 5.933 & 0.5801 & 9.2121 & 0.4322 & 2398 \\
\hline 3 & 1.30 & 103 & 96 & 1530 & 5.612 & 0.5601 & 8.6314 & 0.4060 & 2393 \\
\hline 4 & 0.50 & 152 & 184 & 1960 & 5.971 & 0.5812 & 6.9612 & 0.3260 & 2396 \\
\hline \multicolumn{10}{|c|}{ (Mt. Bol'shaya Varaka, olivine gabbronorite dyke (5-77) } \\
\hline 1 & 0.82 & 127 & 241 & 1630 & 6.173 & 4.5011 & 9.2951 & 0.4372 & 2393 \\
\hline $2(b d)$ & 0.60 & 104 & 212 & 1490 & 5.547 & 8.2507 & 9.0262 & 0.4237 & 2397 \\
\hline 3 & 0.63 & 332 & 607 & 1280 & 6.072 & 2.9501 & 8.9004 & 0.4171 & 2399 \\
\hline 4 & 0.68 & 286 & 626 & 1590 & 6.144 & 3.1284 & 7.5613 & 0.3543 & 2399 \\
\hline
\end{tabular}


${ }^{1}$ The ratios are corrected for blanks of $0.08 \mathrm{ng}$ for $\mathrm{Pb}$ and $0.04 \mathrm{ng}$ for $\mathrm{U}$ and for mass discrimination $0.17 \pm 0.05 \%$. ${ }^{2}$ Correction for common $\mathrm{Pb}$ was determined for the age according to Stacey and Kramers (1975).

Table 5. Summary of U-Pb and Sm-Nd geochronology for layered intrusions located in the eastern Baltic Shield

\begin{tabular}{llll}
\hline & \multicolumn{3}{c}{ Age (Ma) } \\
\cline { 2 - 3 } Layered intrusions & $\mathrm{U}-\mathrm{Pb}$ & $\mathrm{Sm}-\mathrm{Nd}$ & $\mathrm{U} / \mathrm{Pb}$ age
\end{tabular}

\section{Northern belt}

Mt. Generalskaya

gabbronorite

$2496 \pm 10^{1}(2505 \pm 1.6)^{2} \quad 2453 \pm 42^{1}$

anorthosite

$2446 \pm 10^{1}$

Monchepluton

Mt. Travyanaya, norite

$2507 \pm 9^{15}$

Dunite block, gabbronorite dyke

$2506 \pm 10^{15} ; 2496 \pm 14^{15}$

Nyud Terrace, gabbronorite

$2500 \pm 5^{14}$

$2493 \pm 7^{1}(2504 \pm 1.5)^{2}$

Nyud Terrace, gabbronorite

$2497 \pm 21^{15}$

Main Ridge

Monchetundra, gabbro

$2463 \pm 25^{4} ; 2453 \pm 4^{5}$

Monchetundra, gabbronorite

$2505 \pm 6^{14} ; 2501 \pm 8^{14}$

Chunatundra, anorthosite

$2467 \pm 7^{15}$

Ostrovsky intrusion

gabbronorite-pegmatite

Fedorov-Pansky Complex

orthopyroxenite

$2445 \pm 11^{15}$

olivine gabbro

magnetite gabbro

gabbronorite

$\mathrm{Cu}-\mathrm{Ni}$ PGE-bearing gabbronorite

$2526 \pm 6^{12}$

$2516 \pm 7^{12}$

$2498 \pm 5^{6}$

$2491 \pm 1.5^{7}(2501 \pm 1.7)^{2} \quad 2487 \pm 51^{7} \quad-2.1$

$2485 \pm 9^{12}$

$2470 \pm 9^{7}$

PGE-gabbro-pegmatite

$2447 \pm 12^{7}$

Imandra lopolith

gabbronorite 
gabbro-diorite-pegmatite

leucogabbro-anorthosite

olivine gabbronorite (dyke)

\section{Southern belt}

Kivakka

olivine gabbronorite

Lukkulaisvaara

pyroxenite

Tsipringa

gabbro

Burakovskaya intrusion

gabbronorite

Kovdozero intrusion

pegmatoid gabbronorite

Finnisn group

Koitelainen

Koilismaa

Nyaryankavaara

Penikat

$2445 \pm 2^{7}$

$2439 \pm 29^{8}$

$-1.2$

$2439 \pm 11^{7}(2442 \pm 1.9)^{2} \quad 2388 \pm 59^{8} \quad-2.4$

$\begin{array}{lll}2441 \pm 1.2^{2} & 2430 \pm 26^{8} & -1.1\end{array}$

$2449 \pm 1.1^{2} \quad 2365 \pm 90^{8} \quad-2.0$

$2436 \pm 9^{6}$

$2433 \pm 8^{9}$

$2437 \pm 49^{11} \quad-2.0$

$2436 \pm 5^{10}$

$2440 \pm 16^{10}$

Akanvaara

$2437 \pm 7^{11}$

$\begin{array}{ll}2410 \pm 64^{9} & -1.6 \\ 2423 \pm 49^{11} & -2.1\end{array}$

1. Bayanova et al., 1999

6. Bayanova, 2004

11. Hanski et al., 2001

2. Amelin et al., 1995

7. Balashov et al., 1993

12. Nitkina, 2006

3. Tolstikhin et al., 1992

8. Amelin, Semenov,

13. Serov et al., 2007

4. Vrevsky, Levchenkov, 1990

14. Bayanova \& Mitrofanov, 2005 1992

9. Huhma et al., 1990

15. present study

5. Mitrofanov et al., 1993

10. Alapieti et al., 1990

Table 6. Sm-Nd isotope data on whole rock and mineral separates of the Fedorov Block of the Fedorovo-Pansky Complex (from Serov et al., 2007)

\begin{tabular}{|c|c|c|c|c|c|c|c|}
\hline \multirow{2}{*}{$\begin{array}{c}\text { Sample } \\
\text { No }\end{array}$} & \multicolumn{2}{|c|}{$\begin{array}{c}\text { Concentration } \\
\text { (ppm) }\end{array}$} & \multicolumn{2}{|c|}{ Isotopic ratios } & \multirow{2}{*}{$\begin{array}{l}\mathrm{T}_{\mathrm{DM}} \\
(\mathrm{Ga})\end{array}$} & \multirow{2}{*}{$\begin{array}{c}\text { Sm-Nd } \\
\text { (Ma) }\end{array}$} & \multirow{2}{*}{$\varepsilon_{\mathrm{Nd}}(2.5 \mathrm{Ga})$} \\
\hline & $\mathrm{Sm}$ & $\mathrm{Nd}$ & ${ }^{147} \mathrm{Sm} /{ }^{144} \mathrm{Nd}$ & ${ }^{143} \mathrm{Nd} /{ }^{144} \mathrm{Nd}$ & & & \\
\hline \multicolumn{8}{|c|}{ (orthopyroxenite $(F-3)$} \\
\hline WR & 0.32 & 1.17 & 0.1648 & $0.512196 \pm 12$ & 3.05 & $2521 \pm 42$ & -1.73 \\
\hline Opx & 0.12 & 0.38 & 0.2228 & $0.513182 \pm 16$ & & & \\
\hline Cpx & 2.21 & 7.67 & 0.1745 & $0.512349 \pm 17$ & & & \\
\hline $\mathrm{Pl}$ & 0.26 & 1.62 & 0.0960 & $0.511071 \pm 29$ & & & \\
\hline \multicolumn{8}{|c|}{ (olivine gabbro $(F-4)$} \\
\hline WR & 0.63 & 2.80 & 0.1357 & $0.511548 \pm 8$ & 2.94 & $2516 \pm 35$ & -1.53 \\
\hline Opx & 0.23 & 0.72 & 0.1951 & $0.512555 \pm 15$ & & & \\
\hline Cpx & 0.83 & 2.28 & 0.2187 & $0.512947 \pm 16$ & & & \\
\hline Pl & 0.24 & 1.77 & 0.0815 & $0.510677 \pm 14$ & & & \\
\hline \multicolumn{8}{|c|}{ (PGE-bearing gabbronorite $(F-2)$} \\
\hline WR & 0.42 & 1.66 & 0.1537 & $0.511807 \pm 20$ & 3.18 & $2482 \pm 36$ & -2.50 \\
\hline $\mathrm{Pl}$ & 0.41 & 2.88 & 0.0865 & $0.510709 \pm 14$ & & & \\
\hline $\mathrm{Cpx}$ & 1.78 & 5.73 & 0.1876 & $0.512387 \pm 8$ & & & \\
\hline Opx & 0.13 & 0.33 & 0.2323 & $0.513088 \pm 40$ & & & \\
\hline
\end{tabular}


Table 7. REE data for rocks of the Monchepluton 


\begin{tabular}{|c|c|c|c|c|c|c|c|c|c|c|c|c|}
\hline \multirow{2}{*}{ 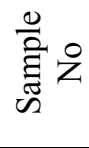 } & 1 & 2 & 3 & 4 & 5 & 6 & 7 & 8 & 9 & 10 & 11 & 12 \\
\hline & \multicolumn{2}{|c|}{ dunites $(M-1)$} & \multicolumn{3}{|c|}{ bronzitites $(M-1)$} & \multicolumn{5}{|c|}{ gabbroids (M-42) } & \multicolumn{2}{|c|}{$\begin{array}{c}\text { tholeiite dykes } \\
(M-1)\end{array}$} \\
\hline $\mathrm{La}$ & 0.216 & 0.102 & 0.754 & 0.479 & 0.302 & 5.020 & 3.030 & 61.30 & 4.910 & 1.700 & 0.635 & 0.780 \\
\hline $\mathrm{Ce}$ & 0.532 & 0.419 & 1.540 & 1.050 & 0.716 & 11.400 & 6.290 & 134.00 & 10.500 & 3.740 & 2.340 & 2.61 \\
\hline $\operatorname{Pr}$ & 0.082 & 0.063 & 0.192 & 0.140 & 0.081 & 1.450 & 0.825 & 17.40 & 1.310 & 0.489 & 0.495 & 0.52 \\
\hline $\mathrm{Nd}$ & 0.420 & 0.294 & 0.784 & 0.614 & 0.383 & 6.160 & 3.550 & 73.10 & 5.510 & 2.150 & 3.540 & 3.43 \\
\hline $\mathrm{Sm}$ & 0.110 & 0.083 & 0.140 & 0.161 & 0.081 & 1.500 & 0.938 & 18.80 & 1.250 & 0.637 & 1.820 & 1.41 \\
\hline $\mathrm{Eu}$ & 0.029 & 0.034 & 0.072 & 0.045 & 0.042 & 0.596 & 0.464 & 7.32 & 0.585 & 0.368 & 0.896 & 0.60 \\
\hline $\mathrm{Gd}$ & 0.104 & 0.086 & 0.216 & 0.192 & 0.178 & 1.590 & 0.911 & 16.40 & 1.290 & 0.713 & 2.500 & 1.8 \\
\hline $\mathrm{Tb}$ & 0.018 & 0.013 & 0.037 & 0.026 & 0.021 & 0.238 & 0.161 & 2.97 & 0.198 & 0.123 & 0.399 & 0.33 \\
\hline Dy & 0.137 & 0.117 & 0.278 & 0.227 & 0.178 & 1.530 & 1.040 & 17.50 & 1.240 & 0.847 & 2.970 & 2.26 \\
\hline Ho & 0.026 & 0.021 & 0.059 & 0.044 & 0.047 & 0.325 & 0.231 & 3.98 & 0.289 & 0.175 & 0.657 & 0.49 \\
\hline $\mathrm{Er}$ & 0.083 & 0.051 & 0.190 & 0.135 & 0.118 & 0.980 & 0.607 & 11.80 & 0.842 & 0.578 & 1.880 & 1.47 \\
\hline $\mathrm{Tm}$ & 0.014 & $<$ l.d. & 0.030 & 0.025 & 0.023 & 0.169 & 0.091 & 1.84 & 0.118 & 0.084 & 0.315 & 0.22 \\
\hline $\mathrm{Yb}$ & 0.107 & 0.072 & 0.232 & 0.230 & 0.193 & 0.968 & 0.670 & 11.10 & 0.742 & 0.548 & 1.810 & 1.32 \\
\hline $\mathrm{Lu}$ & 0.012 & $<$ l.d. & 0.044 & 0.033 & 0.036 & 0.168 & 0.107 & 1.81 & 0.127 & 0.086 & 0.279 & 0.21 \\
\hline
\end{tabular}

REE determinations were measured by Ion probe Cameca 4F analyses by E. Deloule at the Centre de Recherches Petrographiques et Chimiques - CRPG-CNRS, Nancy. The data are provided by the Russian-French project RFFICNRS 01-05-22001 that was headed by the authors of the present study.

* - <1.d.- below limit of determination 
Average standard values: $\mathrm{N}=11$ (La Jolla: $=0.511833 \pm 6) ; \mathrm{N}=100(\mathrm{JNdi1}:=0.512098 \pm 15)$.

\begin{tabular}{|c|c|c|c|c|c|c|c|}
\hline \multirow[t]{2}{*}{ Sample } & \multirow[t]{2}{*}{ Rock type } & \multicolumn{2}{|c|}{$\begin{array}{c}\text { Concentration } \\
(\mathrm{ppm})\end{array}$} & \multicolumn{2}{|c|}{ Isotope ratios } & \multirow[t]{2}{*}{$\begin{array}{l}\mathrm{T}_{\mathrm{DM}} \\
(\mathrm{Ga})\end{array}$} & \multirow[t]{2}{*}{$\varepsilon_{\mathrm{Nd}}$} \\
\hline & & $\mathrm{Sm}$ & $\mathrm{Nd}$ & ${ }^{147} \mathrm{Sm} /{ }^{144} \mathrm{Nd}$ & ${ }^{143} \mathrm{Nd} /{ }^{144} \mathrm{Nd} \pm 2 \sigma$ & & \\
\hline \multicolumn{8}{|c|}{ (Monchepluton) } \\
\hline M-1 & Mineralized norite & 1.750 & 8.04 & 0.131957 & $0.511493 \pm 3$ & 2.91 & -1 \\
\hline M-2 & Gabbronorite-pegmatite & 0.920 & 4.15 & 0.134055 & $0.511537 \pm 4$ & 2.90 & -1 \\
\hline M-42 & Metagabbronorite & 1.480 & 6.67 & 0.134404 & $0.511462 \pm 3$ & 2.85 & -2 \\
\hline C-1 & Orthopyroxenite & 0.564 & 2.56 & 0.133100 & $0.511477 \pm 6$ & 3.09 & -2 \\
\hline $\mathrm{H}-4$ & Olivine pyroxenite & 0.584 & 2.60 & 0.136000 & $0.511577 \pm 8$ & 3.01 & -1 \\
\hline $\mathrm{H}-7$ & Gabbronorite & 0.703 & 3.06 & 0.138900 & $0.511680 \pm 5$ & 3.07 & -1 \\
\hline \multicolumn{8}{|c|}{ (Monchetundra) } \\
\hline M-54 & Trachytoid gabbronorite & 0.940 & 3.54 & 0.159479 & $0.511963 \pm 5$ & 3.08 & -1 \\
\hline \multicolumn{8}{|c|}{ (Chunatundra) } \\
\hline M-16 & Trachytoid anorthosite & 0.730 & 3.08 & 0.143365 & $0.511740 \pm 5$ & 2.84 & -( \\
\hline \multicolumn{8}{|c|}{ (Mt. Yarva-Varaka) } \\
\hline M-38 & Granophyric quartz diorite & 7.380 & 38.48 & 0.115923 & $0.511184 \pm 2$ & 2.91 & -2 \\
\hline \multicolumn{8}{|c|}{ (Ostrovsky intrusion) } \\
\hline M-7 & Gabbronorite- pegmatite & 3.820 & 18.69 & 0.123446 & $0.511333 \pm 2$ & 2.90 & -2 \\
\hline \multicolumn{8}{|c|}{ (dyke rocks of the Monchepluton) } \\
\hline M-9 & Coarse-grained melanonorite & 0.469 & 2.24 & 0.126386 & $0.511354 \pm 5$ & 2.96 & -2 \\
\hline M-12 & Gabbronorite dyke & 0.581 & 2.35 & 0.149344 & $0.511795 \pm 11$ & 2.98 & -1 \\
\hline M-14 & Gabbronorite dyke & 1.770 & 8.86 & 0.120709 & $0.511573 \pm 4$ & 2.40 & 3 \\
\hline
\end{tabular}

Table 9. Sm-Nd and Rb-Sr isotope data for rocks of the Mt. Generalskaya, Fedorovo-Pansky, Imandra, Monchepluton and Monchetundra intrusions 


\begin{tabular}{|c|c|c|c|c|c|c|c|c|}
\hline \multirow{2}{*}{$\begin{array}{l}\text { Sample } \\
\text { No }\end{array}$} & \multicolumn{2}{|c|}{$\begin{array}{l}\text { Concentration } \\
\text { (ppm) }\end{array}$} & \multicolumn{2}{|c|}{ Isotopic ratios } & \multirow{2}{*}{$\varepsilon_{\mathrm{Nd}}(2.5 \mathrm{Ga})$} & \multirow{2}{*}{$\begin{array}{l}\mathrm{T}_{\mathrm{DM}} \\
(\mathrm{Ga})\end{array}$} & \multirow[t]{2}{*}{${ }^{87} \mathrm{Rb} /{ }^{86} \mathrm{Sr}$} & \multirow{2}{*}{$\begin{array}{c}{ }^{87} \mathrm{Sr} /{ }^{86} \mathrm{Sr}( \pm 2 \sigma) \\
\text { @ } 2.5 \mathrm{Ga}\end{array}$} \\
\hline & $\mathrm{Sm}$ & $\mathrm{Nd}$ & ${ }^{147} \mathrm{Sm} /{ }^{144} \mathrm{Nd}$ & ${ }^{143} \mathrm{Nd} /{ }^{144} \mathrm{Nd}( \pm 2 \sigma)$ & & & & \\
\hline \multicolumn{9}{|l|}{ (Mt. Generalskaya) } \\
\hline $\begin{array}{l}\text { S-3464, gabbronorite } \\
\text { (Fedorov-Pansky intrusion) }\end{array}$ & 1.147 & 5.362 & 0.129320 & $0.511449 \pm 14$ & -2.30 & 2.91 & 0.00534 & $0.70421 \pm 22$ \\
\hline Pan-1, gabbronorite & 0.762 & 3.293 & 0.139980 & $0.511669 \pm 7$ & -2.00 & 2.98 & 0.00135 & $0.70315 \pm 10$ \\
\hline Pan-2, gabbronorite & 0.423 & 1.662 & 0.153714 & $0.511807 \pm 20$ & -2.50 & 3,18 & 0.00174 & $0.70295 \pm 17$ \\
\hline$F-4$, olivine gabbro & 0.629 & 2.801 & 0.135695 & $0.511548 \pm 8$ & -1.53 & 2.94 & 0.00144 & $0.70288 \pm 22$ \\
\hline $\begin{array}{l}\text { F-3, orthopyroxenite } \\
\text { (Imandra lopolith) }\end{array}$ & 0.318 & 1.166 & 0.164803 & $0.512196 \pm 12$ & -1.73 & 3.05 & 0.00205 & $0.70333 \pm 15$ \\
\hline $\begin{array}{l}\text { 6-57, gabbronorite } \\
\text { (Monchepluton) }\end{array}$ & 2.156 & 10.910 & 0.119130 & $0.511380 \pm 3$ & -2.00 & 2.88 & 0.00339 & $0.70455 \pm 27$ \\
\hline M-1, quartz norite & 1.750 & 8.040 & 0.131957 & $0.511493 \pm 3$ & -1.51 & 2.91 & 0.01053 & $0.70341 \pm 9$ \\
\hline $\begin{array}{l}\text { H-7, gabbronorite } \\
\text { (Monchetundra) }\end{array}$ & 0.920 & 4.150 & 0.134055 & $0.511537 \pm 4$ & -1.37 & 2.90 & 0.00227 & $0.70368 \pm 24$ \\
\hline $\begin{array}{l}\text { MT- } 10, \text { medium- } \\
\text { grained pyroxenite }\end{array}$ & 0.483 & 1.913 & 0.152689 & $0.511925 \pm 33$ & -0.36 & 2.81 & 0.00495 & $0.70399 \pm 17$ \\
\hline
\end{tabular}

Table 10. Isotopic ${ }^{4} \mathrm{He} /{ }^{3} \mathrm{He}$ ratios of PGE layered intrusions of the Baltic Shield (data are provided by Kamensky and Novikov, Geological Institute KSC RAS, unpublished) 


\begin{tabular}{|c|c|c|c|c|}
\hline $\begin{array}{l}\text { Hole No/sampling } \\
\text { depth (m) }\end{array}$ & Rock, mineral & $\begin{array}{l}{ }^{4} \mathrm{He} \times 10^{-6} \\
\mu \mathrm{cm}^{3} / \mathrm{g}\end{array}$ & $\begin{array}{c}{ }^{4} \mathrm{He} /{ }^{3} \mathrm{He} \\
\times 10^{6} \\
\end{array}$ & $\begin{array}{c}\text { Low Mantle } \\
\text { contribution**\% }\end{array}$ \\
\hline \multicolumn{5}{|c|}{ (Fedorovo-Pansky intrusion) } \\
\hline hole, Ki-16/6 & Amphibole & 81.00 & 9.10 & 0.11 \\
\hline hole, Ma-14/1 & Orthopyroxene & 9.90 & 12.80 & 0.08 \\
\hline outcrop, No 9 & Ilmenite & 43.90 & 16.50 & 0.06 \\
\hline \multicolumn{5}{|c|}{ (Monchepluton, Mt. Sopcha) } \\
\hline hole, $995 / 315$ & Olivinite, rock & 17.00 & 6.25 & 0.16 \\
\hline hole, $995 / 315$ & Olivine & 25.00 & 5.88 & 0.17 \\
\hline hole, $995 / 315$ & Orthopyroxene & 31.00 & 6.25 & 0.16 \\
\hline hole, $995 / 315$ & Plagioclase & 47.00 & 5.56 & 0.18 \\
\hline hole, $995 / 315$ & Magnetite & 132.00 & 4.35 & 0.23 \\
\hline \multicolumn{5}{|c|}{ (Main Ridge, Monchetundra) } \\
\hline hole, $765 / 905,9$ & Clinopyroxene & 163.00 & 4.76 & 0.21 \\
\hline hole, 765/905,9 & Orthopyroxene & 21.00 & 4.76 & 0.21 \\
\hline hole, $765 / 985,3$ & Amphibole & 97.00 & 4.76 & 0.21 \\
\hline hole, $765 / 985,3$ & Clinopyroxene & 115.00 & 5.00 & 0.20 \\
\hline outcrop, MT-5 & Gabbro & 1.30 & 2.00 & 0.41 \\
\hline \multicolumn{5}{|l|}{ (Dunite block) } \\
\hline hole, $904 / 102$ & Dunite, rock & 218.00 & 1.47 & 0.68 \\
\hline hole, 904/102 & Olivine & 115.00 & 1.35 & 0.74 \\
\hline hole, $1651 / 244,9$ & Chromitite, ore & 56.00 & 1.43 & 0.70 \\
\hline hole, C-1651/373,5* & Dunite-Bronzitite & 28.00 & 0.83 & 1.20 \\
\hline hole, C-1622/7* & Chromitite, ore & 2.80 & 0.69 & 1.44 \\
\hline hole, C-1646/450* & Dunite & 2.20 & 1.29 & 0.77 \\
\hline hole, C-1651/373.5* & Dunite-Bronzitite-contact & 0.13 & 0.60 & 1.68 \\
\hline
\end{tabular}

